\title{
Changes in Landscape Structure in the Municipalities of the Nitra District (Slovak Republic) Due to Expanding Suburbanization
}

\author{
Zuzana Pucherová *, Regina Mišovičová, Gabriel Bugár and Henrich Grežo (D) \\ Department of Ecology and Environmental Sciences, Faculty of Natural Sciences, \\ Constantine the Philosopher University, 94901 Nitra, Slovakia; rmisovicova@ukf.sk (R.M.); \\ gbugar@ukf.sk (G.B.); hgrezo@ukf.sk (H.G.) \\ * Correspondence: zpucherova@ukf.sk
}

Citation: Pucherová, Z.; Mišovičová, R.; Bugár, G.; Grežo, H. Changes in Landscape Structure in the Municipalities of the Nitra District (Slovak Republic) Due to Expanding Suburbanization. Sustainability 2021, 13, 1205. https://doi.org/10.3390/ su13031205

Received: 16 December 2020

Accepted: 20 January 2021

Published: 24 January 2021

Publisher's Note: MDPI stays neutral with regard to jurisdictional claims in published maps and institutional affiliations.

Copyright: (c) 2021 by the authors. Licensee MDPI, Basel, Switzerland. This article is an open access article distributed under the terms and conditions of the Creative Commons Attribution (CC BY) license (https:// creativecommons.org/licenses/by/ $4.0 /)$.

\begin{abstract}
Suburbanization, as a set of several factors, influences and changes the landscape structure of smaller municipalities in the hinterland of larger cities. The purpose of this paper is to evaluate the built-up areas related to suburbanization within three time horizons—in 2002, 2005, and 2020—in 62 municipalities of the district (including two cities, Nitra and Vráble). This study examines the process of spatial changes in landscape features (residential, industrial, agricultural, transport) related to suburbanization between 2002 and 2005 and between 2002 and 2020. The input analytical data were digital orthophotomaps from 2002 and 2005 and the current orthophotomosaics of the Slovak Republic from 2017 (GKÚ, Bratislava), updated for the year 2020 using Sentinel 2 satellite image data (European Space Agency). The impact of suburbanization processes between 2002 and 2005 did not reach the dimensions of the changes that occurred due to suburbanization processes between 2002 and 2020 or 2005 and 2020. The main research objective of the article is the identification and assessment of these changes. We determined which landscape features related to suburbanization affected spatial changes in municipalities of the district Nitra. The total area affected by one of the suburbanization processes monitored by us reached 92.52 ha in the period between 2002 and 2005 . Between the years 2002 and 2020, the area reached a total of $2272.82 \mathrm{ha}$, which is an increase of 2180.30 ha in 2020 compared to 2002. This included mainly the expansion of settlements or housing $(60.15 \%)$, industrial areas $(29.31 \%)$, transport facilities $(4.35 \%)$, agricultural areas $(0.73 \%)$, and other areas (5.46\%). These results show expanding suburbanization for the period from 2002 to 2020 and that this process has been gaining momentum in the municipalities of the Nitra district, especially in recent years, which changes the look of rural municipalities and the character of a typical rural landscape.
\end{abstract}

Keywords: land use; landscape structure; changes; built-up areas; suburbanization; suburban landscape

\section{Introduction}

Suburbanization is a relatively complex process that is caused by several interdependent factors. Many of them affect the growth of cities, while others have a positive effect on the gradual urban sprawl to the surrounding countryside [1]. Suburbanization involves the tendency for the average residential household (or a firm) to locate at an increasing distance from the city center [2]. The term suburbanization is understood, in general, as a development of the surroundings while the core is dwindling or stable; there is no singular commonly accepted model of suburbanization [3]. Suburbanization has specific demographic, morphological, social, economic, and technical dimensions [4]. The suburb is not just a place (or a location) but a process, as well as a way of life [5].

Suburbanization is visibly manifested by the growth and spatial expansion of buildings in the immediate hinterland of the city and also in the context of its functional relationships, residential and transport network, and natural conditions. This expansion is 
an integral part of urban development, which is made possible, in particular, by transport options and efficient accessibility to the center [6]. Suburbanization is one of the main factors that has dramatically changed the urban structure of cities and nearby settlements in Eastern Europe over the last three decades [7]. Suburbanization processes have been identified and described in many papers. One of the major developments in postsocialist cities is the increasing outflow of people from the city to the surrounding settlements. Suburbanization seems to be a radial process; people tend to cross the city boundary at the shortest distance and settle in one of the nearest settlements [8]. Residential suburbanization is one of the most spontaneous processes occurring in the surroundings of large cities in Central and Eastern Europe, and it is one of the forms of suburban development [9]. The postsocialist period marks a pivotal point in the evolution of cities in Central and Eastern Europe [10].

According to many experts, suburbanization is the most typical process that defines the development of urbanized areas. Suburbanization is often labeled the main process transforming the character of the landscape and the shape of municipalities in the countryside around cities [11-14], with many environmental problems in most cases [15]. Suburbanization has been one of the most spectacular spatial processes of the 1990s in several East-Central European countries [11]. The suburbanization drivers include economic factors (e.g., globalization, EU integration, rising living standards, land prices, national policies, demography), housing preferences, social factors, transportation, and regulatory frameworks [16]. The residential and industrial areas are moved to rural areas (the surroundings of cities). Therefore, there are land-use and land-cover changes, especially from agricultural to urbanized [17].

Suburban processes in the Slovak Republic (SR) started, as is the case in other postsocialist countries, after the period of socialism. This delay was caused by the delay of urbanization processes compared to Western Europe. This period, unfavorable for suburbanization, was caused by the relatively equal price of land in rural and urban areas, the preference for center-municipalities, limited construction of family houses in the countryside and on the outskirts of urban settlements, and the growth of industrial production in cities [18]. For cities, the construction of housing estates, with a unified construction of high-rise panel buildings, currently referred to as mass (collective) housing construction, was typical. The change did not occur until 1989 ("the Velvet Revolution") and the beginning of the 1990s (political and social changes), when the hitherto functioning industrial production in cities underwent a process of transformation into a market economy. This process brought with it several changes, e.g., reduction of production in industry, the emerging modern phenomenon of unemployment, significant differences in the prices of urban and rural land, and the provision of then-unknown mortgage loans.

The result of this transformation process is an emerging process of sociospatial change in the settlement of rural communities in the vicinity of larger cities [19]. Suburbanization processes, determined mainly in the past three decades by population migration and social and economic incentives, have distinctly transformed the character and land use in the hinterland of major Slovak cities [6]. The issue of the suburbanization process using the example of Slovak cities has been addressed by several authors, e.g., around the city of Bratislava [20,21], the city of Košice [22], the city of Prešov [23], the city of Trnava [24], and the city of Nitra [14,25]. The model of a monofunctional residential suburb, commuting to work, school, and services from the rural environment to urban areas, creates numerous pressures for the rational functioning of the affected areas. The inability to comprehensively develop suburban rural communities is most often presented because of inappropriate approaches in the past and a current lack of funding, which limits their sustainability [26].

One of the most important territorial processes in the highly urbanized continent of Europe is suburbanization-urban sprawl that occurs in a gradual manner over long periods and is not perceived as dramatic. Urban sprawl affects the essential environmental, economic, and social functions of the impacted municipalities. In the last decades, these processes have reached the less urbanized Central European region, leading to very fast 
and less-planned changes in its settlement system [25]. Several studies show that the changes in land use since the 1990s are very similar to former postcommunist countries.

Suburbanization is the most typical process that defines the development of urbanized areas in Central and Eastern Europe [12]. The processes of suburbanization and the expansion of the two main postsocialist cities in Southeast Europe, i.e., Belgrade (Serbia) and Sofia (Bulgaria), are examined for the effects of inherited conditions from the era of state socialism and the effects of socioeconomic changes in the transition to suburban form and trends. At the same time, they are examined as to whether and what extent these trends can be identified as suburbanization and expansion and as to the local specificities [27]. The development of suburbanization processes in Polish metropolitan areas during the political transition from communism is assessed in the paper [28] by using and, subsequently, analyzing population and migration data for municipalities in seven metropolitan areas from 1995 to 2012. The results show that the phase of suburban development is strongly linked to the size and level of economic development of the cities.

Another paper has addressed the extent of suburbanization in Ukraine and the identification of the relationship between city size and the development of suburbanization and regional specificities [12]. Suburbanization processes in Ukraine are extremely widespread. The analysis is based on data on the dynamics of migration in urban cores, suburban areas, and inland areas of 65 cities with more than 40,000 inhabitants, located in 22 regions of Ukraine. However, large-scale restructuring of the economy in the post-Soviet period had a critical role in the development of individual and regional differences in urban development.

The process of urbanization in Romania was slightly different compared to other Central and Eastern European countries; it is marked by the constant willingness to increase the degree of urbanization. The communist period was the most significant from this point of view, considering both the number of newly declared towns and urban population growth. The urbanization of the communist era corroborated with excessive and forced industrialization to generate imbalances in the urban system and create distortions in the urban hierarchy. The authors focused on identifying the driving force and the consequences of two opposing processes: socialist-forced urbanization vs. postsocialist chaotic urbanization developing across the national urban landscape [29]. The intensive suburbanization processes are evaluated using the example of the Bulgarian capital, pointing to the peripheral growth of the city of Sofia and including economic factors as one of the important factors of suburban development in this area [10].

Similarly, the development of suburbanization has been analyzed in the metropolitan areas of Prague and Brno in the Czech Republic [30]. Residential deconcentration in these cities has brought about a spatial redistribution of population in the metropolitan areas, while the total population has stagnated. Suburbanization is identified using the example of other Czech cities. The negative and positive impacts of suburbanization processes are identified in the surrounding municipalities in the suburban zone of the city of Olomouc [31]. The example of the South Bohemian town of České Budějovice is evaluated on the gradual increase in the city's population until 1998 and the subsequent decrease in population, mainly due to suburban migration, including problems of territorial development of the emerging suburb and the increase in the number of suburbs around the town (from 13 in 1989 to 53 by 2017) [32]. The bicentric residential agglomeration of Hradec Králové-Pardubice is described in terms of the development of suburbanization in relation to transport infrastructure connecting all important centers. Since 2000, more than 14,500 flats have been completed in the agglomerated area. Impermeability and limited flow of traffic have had negative effects on the economic development of the whole territory [33]. The suburban countryside, with extended competence, is evaluated in six areas in the background of large Czech cities (Brno, Ostrava, Zlín), which occupies 7\% of the area of the Moravia region [34]. Some statistical data are also used to assess the development of the population in the peripheral area of Moravia in the period 2012-2016 
in relation to suburbanization; the suburbanized countryside shows a definite population increase [35].

Suburbanization, as a new phenomenon, is described in the example of the urban settlements of Budapest, Debrecen, and Szeged within the Great Hungarian Plain. In the 1960s, these "socialist" cities were hit by industrial decentralization. The result was insufficient housing options in urban settlements, with a more attractive offer of cheaper land for sale in their suburbs. In the 1980s, migration started from these centers to the surrounding areas, leading to significant population growth and faster construction in neighboring villages [36].

Another example of so-called cross-border suburbanization and the related processes are presented for the municipality of Rajka. The migration of the urban population from Bratislava, the capital of Slovakia, to a not-too-remote rural area $(15 \mathrm{~km})$, although located in another country, has transformed the original character of Rajka. This village is becoming a growing "Hungarian suburb" of the Slovak capital. The population in Rajka more than doubled between 2007 and 2017, of which 60\% are Slovak nationals. The new inhabitants occupy a total of 500 properties (two-thirds of the properties are houses in the newly built eastern part of the village). In the absence of new building plots of land, many have moved to older streets, and the original population tends to move out. The authors cite the main impacts of this cross-border suburbanization, such as growing population, more intensive transport, changes in the community, social transformation, coexistence in the community (linguistic and social relations), relationship to daily economic life in the community, conflicts of interest between immigrants and local people, better financial background of the new population compared to the original population, ethnic-linguistic conflict, existing problems with integration, and a general change in the appearance of the municipality. Demand for real estate remains high [37].

In the second half of the twentieth century, the suburbanization process became a central feature of urban development in almost all Western industrialized countries and a major reason for an increase of inner-city population losses, especially in the United States. In this period, the process of rapid urbanization within Western industrial countries slowly came to an end and, in some regions, passed into processes of stagnation or population decline. The number of shrinking cities began to rise, from which quantitative terms can be characterized by a population decrease within a defined urban territory. In the late 20th century, the first concentrations of shrinking cities appeared in Central European countries as well because, in the 1990s, the dramatic political and economic transformations in Eastern European countries caused serious urban crises [38]. The urban boom of European cities is currently taking place through the gradual expansion of urban areas to the surrounding rural or natural (forest) landscape. With respect to the spatial and temporal analysis of urban sprawl, there are some differences between postsocialist countries and other European countries [39]. Unlike Western countries, suburbanization was less pronounced in postsocialist countries because their cities were able to remain compact and densely populated [40].

The assessment of the landscape changes in relation to suburbanization, converting agricultural land to nonagricultural land and urban sprawl, is addressed in many works $[6,24,25,41-54]$.

Since we have expected such development of suburbanization in the vicinity of the town of Nitra, we wanted to describe, in an exact way, the changes in the landscape structure that took place over the course of 20 years-not only in the municipalities immediately adjacent to the town of Nitra but in the whole district of Nitra. We have assumed that residents will look for affordable housing plots in villages that have a good connection to the traffic infrastructure in the towns in the district of Nitra (Nitra and Vráble), which will also provide residents with an economic, cultural, and social background. In addition to housing, the suburbanization process also covers the construction of industrial, agricultural, and transport facilities. 
The aim of our paper is to point out the development and changes of the landscape structure in 62 municipalities of the Nitra district with regard to built-up areas in three time horizons-in 2002, 2005, and 2020. With their mutual comparison (between 2002 and 2005 and between 2002 and 2020), we want to point out the expanding suburbanization, which is gaining intensity in the evaluated area in terms of construction of residential or housing developments and the expansion of industrial and agricultural areas, transport facilities, and other areas related to suburbanization.

The following hypotheses were formulated for the purpose of this research:

Hypothesis 1 (H1). Due to the growing number of inhabitants and the suburbanization in the rural settlements of the Nitra district, the number of inhabitants in the two cities (Nitra and Vráble) has decreased between 2002 and 2020.

Hypothesis 2 (H2). The rural municipalities of the Nitra district were affected by suburbanization processes in the years 2002 to 2020, which resulted in a change in their landscape structure.

Hypothesis 3 (H3). Changes in land-use related to suburbanization processes in the municipalities of the Nitra district were more pronounced between the period 2005 and 2020 than between 2002 and 2005.

Hypothesis 4 (H4). Of all the types of suburbanization processes, we can observe an increase in residential development in most municipalities in the Nitra district.

Hypothesis 5 (H5). Significant newly emerging socioeconomic factors-such as better transport accessibility and employment opportunities in the industries in the Nitra district-may affect the expanding suburbanization in the rural settlements of the district.

\section{Materials and Methods}

\subsection{Study Area}

The district of Nitra is located in the western part of the Slovak Republic (Figure 1). Administratively, it belongs to the Nitra self-governing region. The Nitra district includes 62 municipalities, of which 2 municipalities have the status of a town: Nitra (which is also a district town) and Vráble. The other 60 municipalities are rural. According to the size category, with regard to the number of inhabitants used by the Statistical Office of the Slovak Republic, the largest number of municipalities has 1999 or fewer inhabitants (46 municipalities in total), with 14 municipalities in the district having 2000-4999 inhabitants, 1 municipality with 5000-9999 inhabitants (the town of Vráble has, as of 1 January 2020, a total of 8551 inhabitants) and 1 municipality in the size category of 50,000-99,999 inhabitants (the town of Nitra has, as of 1 January 2020, a total of 76,533 inhabitants). The smallest municipality in the district is the village of Kapince, with 186 inhabitants. The district of Nitra has an area of $87,071.99$ ha. The population of the district, as of 1 January 2020, was 161,679 inhabitants, with an average population density of 185.68 inhabitants per $\mathrm{km}^{2}$. In terms of number and population density, it is the largest district in the Nitra Region.

In terms of geomorphological division, the district of Nitra belongs to the AlpineHimalayan system and the subsystems of the Carpathians and the Pannonian Basin. The dominant geomorphological unit in the district is the Podunajská pahorkatina (Danubian Hills). The relief in this area is mostly flat and hilly, disturbed only by the Tribeč mountains. The highest point in the district is located in the Tribeč mountains (Žibrica hill, with an altitude of 617 m.a.s.1.). Another important hill is Zobor (587 m.a.s.l.), which is located above the town of Nitra. The lowest place in the district is near the village of Pol'ný Kesov (water level in the Rastislavice reservoir is 122 m.a.s.l.). In the district of Nitra, the predominant soil types include brown earth and chernozem (black soil); medium-heavy soils dominate the soil classes. The territory of the Nitra district falls into a partial drainage area of the river Váh. The hydrological network of the Nitra district consists of the rivers of Nitra and Žitava, while the river Nitra is the most important river in the district. The Nitra 
river flows through the middle of the district, from north to south. From a climatological point of view, the district belongs to a warm area. The average annual temperatures here range from a low of $8.28{ }^{\circ} \mathrm{C}$ to a high of $10.05^{\circ} \mathrm{C}$. The warmest months are June, July, and August, while the coldest months are December, January, and February. The average annual precipitation in the district ranges from a minimum of $529 \mathrm{~mm}$ to a maximum of $895 \mathrm{~mm}$ [55].

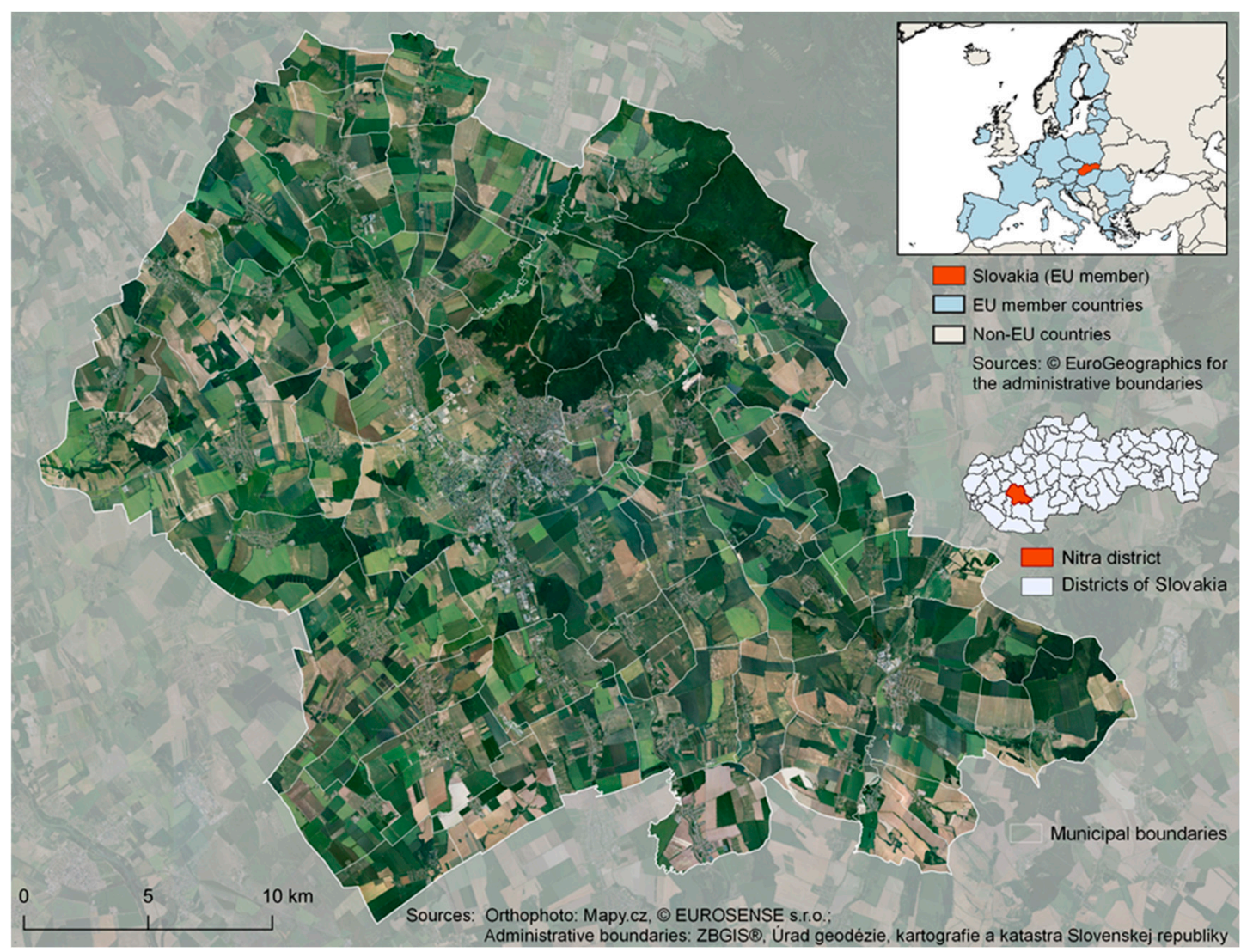

Figure 1. The localization of the study areas in the Slovak Republic.

Of the total area of the district of Nitra $(87,071.99 \mathrm{ha})$, the largest area is agricultural land $(66,915.85 \mathrm{ha}, 76.85 \%$; mainly arable land of 60,318.21 ha), forest land (8835.52 ha, $10.15 \%)$, built-up areas and courtyards (7052.50 ha, $8.10 \%)$, water areas (1356.20 ha, $1.56 \%)$, and other areas (2911.92 ha, 3.34\%) [56].

The following industries have the most significant representation in the district of Nitra: electrical engineering, mechanical engineering, and automotive, chemical, and food industries. In recent years, the district of Nitra has experienced a great boom in industrial production, not only due to the construction of the Nitra-North industrial zone (2005) and the Nitra-South industrial zone (2007), but especially the construction and commissioning of the Jaguar Land Rover Nitra industrial plant (in 2018). The oldest industrial park in the district of Nitra (also the oldest in the Slovak Republic) is the Vráble Industrial Park (since 1995). In recent years, another industrial zone in the village of Čab has been expanding. In some municipalities of the district of Nitra, there are functional agricultural areas (e.g., Nová Ves nad Žitavou, Mojmírovce, Pohranice, Vel'ký Cetín), but several municipalities in the district have former areas of agricultural cooperatives in a desolate state (e.g., Čechynce, Telince, Nitrianske Hrnčiarovce). The total length of all road categories (1st, $2 \mathrm{nd}$, and 3rd class roads) is $434,216 \mathrm{~km}$ within the district of Nitra, with an average density of $0.499 \mathrm{~km} / \mathrm{km}^{2}$. The R1 Pribina expressway passes approximately in the middle of the district of Nitra and connects the city of Nitra with other Slovak cities (Trnava, Žarnovica, Žiar nad Hronom, Zvolen, Banská Bystrica). Within the district of Nitra, the expressway 
was commissioned in 2011, and its total length in the district is $40,276 \mathrm{~km}$. The total length of railway lines in the district of Nitra is $155.75 \mathrm{~km}$. There is only one airport in the district of Nitra. It is the public international airport of Nitra-Janíkovce (ICAO abbreviation LZNI), which lies about $3 \mathrm{~km}$ south of the city of Nitra, in the vicinity of the village of Janíkovce. The airport has an altitude of 135 m.a.s.l. and is currently without regular flights; it provides customs and passport control service for international arrivals by prior arrangement [55]. There are 2 universities in the city of Nitra: the Slovak University of Agriculture and the University of Constantine the Philosopher. The school network is complemented by primary and secondary schools, which are located in several municipalities of the district. At the same time, healthcare is provided in hospitals and polyclinics in the cities of Nitra and Vráble (but also in some rural communities). The district of Nitra is also interesting in terms of the occurrence of natural, cultural, and historical monuments and recreational facilities, while the largest number of them is in the city of Nitra itself.

\subsection{Data and Methodology}

The basic source of information on the development and changes in the landscape structure include the digital orthophotomap layers of the Slovak Republic (C EUROSENSE, s.r.o. from 2002 and 2005 (western part of the Slovak Republic), with a resolution of $1 \mathrm{~m} /$ pixel and three channels (RGB, 8-bit) in the coordinate system S-JTSK (JTSK), with EPSG code 5514. Input analytical data were subsequently vectorized for each time horizon of 2002 and 2005 using Arc View 3.1 software. For the latest time horizon, we used the current orthophotomosaics of the Slovak Republic from 2017 (GKÚ, Bratislava); these were updated for 2020 (as of September 2020) using Sentinel 2 satellite image data (European Space Agency). For vectorization of all 62 municipalities in the district of Nitra, we focused on the built-up areas: (1) residential development (individual development of family houses, collective housing construction), (2) industrial areas (areas of industrial enterprises and plants, mining areas, areas of photovoltaic power plants, incinerator plants, composting plants, biogas stations), (3) agricultural areas (areas of agricultural enterprises, currently complemented by industrial production), (4) transport facilities (road and railway networks, airports, other transport infrastructure), and (5) other residential areas (wastewater treatment plants, collection yards, waste dumps, electrical transformer stations). Using Arc GIS 10.1 software, we used vector data geoprocessing to process spatial statistics and create graphical outputs.

The resulting digital models were used in further analysis and synthesis and in the evaluation of changes between the time periods of 2002 and 2005 and 2002 and 2020. Spatial changes related to urbanization processes were divided into changes related to the expansion of (1) residential, (2) industrial, (3) agroindustrial, (4) traffic, and (5) other areas. We also quantified these changes, i.e., we determined the area (in hectares) or the share of these changes (in percentages) that occurred between individual comparisons of the time periods (2002 and 2005 and 2002 and 2020) within the area of each municipality in the district of Nitra.

Zonal statistics for individual municipalities of the district were processed on the basis of vector layers of administrative units in the ESRI SHP format-Boundaries of territorial and administrative organization of the Slovak Republic in the basic level of ZBGIS (Geodetický a kartografický ústav, Bratislava, Slovakia, 2020).

In this paper, we also compared the obtained results of spatial data with data on changes in the number of inhabitants in individual municipalities of the district of Nitra in 2002, 2005, and 2020. We acquired these data from the Statistical Office of the Slovak Republic [57]. At the same time, we used housing data from the official census of population and housing of 26 May 2001 and 21 May 2011, which is carried out in the Slovak Republic in ten-year cycles $[58,59]$. The next official census of population and housing will be carried out in 2021. 


\section{Results}

Research into urban sprawl is generally based on statistical data relating to demographics and development in administrative units [60,61].

3.1. Changes in the Overall Population in the Municipalities of the District of Nitra in 2002, 2005, and 2020

In the monitored years of 2002, 2005, and 2020, there was an overall decrease in the number of inhabitants in the Nitra self-governing region and in the district of Nitra. In both city settlements (Nitra and Vráble), we recorded a decrease in the number of inhabitants in the monitored period. A total of 87,308 inhabitants lived in the city of Nitra in 2002, and this number decreased to 76,533 in 2020 (Table 1). Similarly, the population decreased in the second town of Vráble (from 9503 in 2002 to 8551 in 2020; Table 1). Hypothesis 1 is confirmed by our results. At the same time, some rural municipalities, such as Alekšince, Čifáre, Kapince, L'udovítová, Malé Zálužie, Vel'ké Chyndice, and Vel'ký Cetín also recorded a decrease in inhabitants. A specific case comes in the form of some municipalities, from which their neighboring municipalities were separated between 2002 and 2020 (Figure 2), which was reflected in a decrease in the number of inhabitants in these municipalities. Conversely, an increase in the number of inhabitants was recorded in the newly established municipalities, e.g., Horné Lefantovce and Dolné Lefantovce, Podhorany, Bádice, and Štitáre, which had separated from the city of Nitra (Table 1). In other municipalities of the district of Nitra, we can see an increase in the number of inhabitants in the period from 2002 to 2020 (Figure 2), while in some municipalities, this increase was significant, e.g., Cabaj-Čápor, Čel'adice, Golianovo, Ivanka pri Nitre, Lehota, Lužianky, Malý Lapáš, Nitrianske Hrnčiarovce, Štitáre, Vel’ké Zálužie, and Vel’ký Lapáš (Table 1).

Table 1. Population and mechanical movement of the population in the municipalities of the district of Nitra in 2002, 2005, and 2020.

\begin{tabular}{|c|c|c|c|c|c|c|c|c|c|c|c|c|}
\hline \multirow{2}{*}{ Municipality } & \multicolumn{4}{|c|}{ Year 2002} & \multicolumn{4}{|c|}{ Year 2005} & \multicolumn{4}{|c|}{ Year 2020} \\
\hline & 1 & 2 & 3 & 4 & 1 & 2 & 3 & 4 & 1 & 2 & 3 & 4 \\
\hline Alekšince & 1669 & 37 & 14 & 23 & 1708 & 29 & 28 & 1 & 1669 & 26 & 35 & -9 \\
\hline Báb & 956 & 19 & 12 & 7 & 960 & 16 & 7 & 9 & 1115 & 31 & 24 & 7 \\
\hline Babindol & 666 & 9 & 8 & 1 & 650 & 12 & 13 & -1 & 808 & 25 & 9 & 16 \\
\hline Bádice & 0 & 0 & 0 & 0 & 337 & 2 & 2 & 0 & 376 & 28 & 3 & 25 \\
\hline Branč & 2024 & 41 & 22 & 19 & 2065 & 42 & 21 & 21 & 2221 & 33 & 42 & -9 \\
\hline Cabaj-Čápor & 3446 & 83 & 34 & 49 & 3562 & 93 & 59 & 34 & 4300 & 86 & 74 & 12 \\
\hline Čab & 675 & 13 & 2 & 11 & 713 & 25 & 7 & 18 & 798 & 18 & 12 & 6 \\
\hline Čakajovce & 1093 & 21 & 30 & -9 & 1069 & 17 & 28 & -11 & 1161 & 34 & 31 & 3 \\
\hline Čechynce & 1026 & 17 & 9 & 8 & 1030 & 10 & 8 & 2 & 1259 & 45 & 24 & 21 \\
\hline Čel'adice & 743 & 9 & 8 & 1 & 762 & 27 & 17 & 10 & 1034 & 42 & 20 & 22 \\
\hline Čifáre & 596 & 14 & 6 & 8 & 648 & 24 & 10 & 14 & 591 & 18 & 12 & 6 \\
\hline Dolné Lefantovce & 0 & 0 & 0 & 0 & 538 & 9 & 5 & 4 & 703 & 30 & 19 & 11 \\
\hline Dolné Obdokovce & 1150 & 0 & 7 & -7 & 1111 & 0 & 13 & -13 & 1184 & 13 & 18 & -5 \\
\hline Golianovo & 1158 & 36 & 18 & 18 & 1196 & 27 & 18 & 9 & 1850 & 61 & 38 & 23 \\
\hline Horné Lefantovce & 1449 & 21 & 16 & 5 & 948 & 42 & 22 & 20 & 894 & 16 & 14 & 2 \\
\hline Host'ová & 372 & 9 & 12 & -3 & 368 & 7 & 11 & -4 & 389 & 11 & 5 & 6 \\
\hline Hruboňovo & 471 & 9 & 7 & 2 & 487 & 17 & 2 & 15 & 519 & 20 & 15 & 5 \\
\hline Ivanka pri Nitre & 2309 & 62 & 63 & -1 & 2417 & 134 & 27 & 107 & 2774 & 84 & 74 & 10 \\
\hline Jarok & 1716 & 17 & 18 & -1 & 1767 & 34 & 24 & 10 & 2036 & 48 & 46 & 2 \\
\hline
\end{tabular}


Table 1. Cont

\begin{tabular}{|c|c|c|c|c|c|c|c|c|c|c|c|c|}
\hline \multirow{2}{*}{ Municipality } & \multicolumn{4}{|c|}{ Year 2002} & \multicolumn{4}{|c|}{ Year 2005} & \multicolumn{4}{|c|}{ Year 2020} \\
\hline & 1 & 2 & 3 & 4 & 1 & 2 & 3 & 4 & 1 & 2 & 3 & 4 \\
\hline Jelenec & 1940 & 22 & 16 & 6 & 1984 & 39 & 28 & 11 & 2116 & 26 & 43 & -17 \\
\hline Jelšovce & 945 & 17 & 12 & 5 & 949 & 20 & 10 & 10 & 994 & 27 & 24 & 3 \\
\hline Kapince & 189 & 5 & 4 & 1 & 193 & 10 & 0 & 10 & 187 & 1 & 5 & -4 \\
\hline Klasov & 1257 & 24 & 5 & 19 & 1214 & 3 & 15 & -12 & 1383 & 22 & 26 & -4 \\
\hline Kolíňany & 1447 & 30 & 25 & 5 & 1465 & 16 & 8 & 8 & 1549 & 15 & 35 & -20 \\
\hline Lehota & 1811 & 11 & 21 & -10 & 1803 & 47 & 15 & 32 & 2212 & 27 & 43 & -16 \\
\hline Lúčnica nad Žitavou & 919 & 6 & 10 & -4 & 911 & 11 & 13 & -2 & 929 & 30 & 14 & 16 \\
\hline L'udovítová & 259 & 9 & 3 & 6 & 258 & 3 & 5 & -2 & 240 & 2 & 1 & 1 \\
\hline Lukáčovce & 1008 & 14 & 16 & -2 & 1084 & 85 & 7 & 78 & 1155 & 33 & 22 & 11 \\
\hline Lužianky & 2476 & 45 & 42 & 3 & 2536 & 66 & 48 & 18 & 2995 & 76 & 83 & -7 \\
\hline Malé Chyndice & 380 & 6 & 2 & 4 & 392 & 6 & 3 & 3 & 390 & 8 & 9 & -1 \\
\hline Malé Zálužie & 269 & 1 & 1 & 0 & 257 & 11 & 4 & 7 & 263 & 10 & 12 & -2 \\
\hline Malý Cetín & 374 & 2 & 2 & 0 & 384 & 21 & 2 & 19 & 438 & 35 & 5 & 30 \\
\hline Malý Lapáš & 366 & 7 & 0 & 7 & 385 & 17 & 7 & 10 & 1074 & 84 & 19 & 65 \\
\hline Melek & 449 & 6 & 6 & 0 & 454 & 9 & 14 & -5 & 482 & 7 & 4 & 3 \\
\hline Mojmírovce & 2703 & 57 & 49 & 8 & 2751 & 61 & 24 & 37 & 2914 & 47 & 39 & 8 \\
\hline Nitra & 87,308 & 908 & 997 & -89 & 85,742 & 1060 & 1555 & -495 & 76,533 & 1341 & 1482 & -141 \\
\hline Nitrianske Hrnčiarovce & 1763 & 48 & 33 & 15 & 1818 & 55 & 27 & 28 & 2108 & 77 & 49 & 28 \\
\hline Nová Ves nad Žitavou & 1288 & 23 & 26 & -3 & 1273 & 24 & 15 & 9 & 1358 & 23 & 18 & 5 \\
\hline Nové Sady & 1305 & 9 & 20 & -11 & 1273 & 17 & 7 & 10 & 1280 & 30 & 32 & -2 \\
\hline Paňa & 290 & 4 & 6 & -2 & 317 & 15 & 16 & -1 & 395 & 36 & 6 & 30 \\
\hline Podhorany & 1390 & 21 & 15 & 6 & 1062 & 21 & 19 & 2 & 1063 & 16 & 26 & -10 \\
\hline Pohranice & 1067 & 22 & 12 & 10 & 1069 & 17 & 12 & 5 & 1096 & 30 & 13 & 17 \\
\hline Pol'ný Kesov & 588 & 12 & 14 & -2 & 610 & 16 & 12 & 4 & 666 & 8 & 10 & -2 \\
\hline Rišňovce & 1921 & 25 & 20 & 5 & 1988 & 34 & 12 & 22 & 2062 & 40 & 35 & 5 \\
\hline Rumanová & 769 & 6 & 13 & -7 & 772 & 17 & 14 & 3 & 820 & 11 & 17 & -6 \\
\hline Svätoplukovo & 1271 & 13 & 13 & 0 & 1308 & 42 & 23 & 19 & 1342 & 28 & 23 & 5 \\
\hline Štefanovičová & 256 & 1 & 5 & -4 & 264 & 10 & 7 & 3 & 367 & 16 & 7 & 9 \\
\hline Štitáre & 0 & 0 & 0 & 0 & 619 & 51 & 15 & 36 & 1003 & 70 & 31 & 39 \\
\hline Šurianky & 570 & 10 & 3 & 7 & 569 & 9 & 7 & 2 & 574 & 4 & 7 & -3 \\
\hline Tajná & 280 & 14 & 2 & 12 & 285 & 10 & 6 & 4 & 281 & 2 & 5 & -3 \\
\hline Telince & 274 & 5 & 7 & -2 & 319 & 28 & 0 & 28 & 427 & 16 & 14 & 2 \\
\hline Vel'ká Dolina & 567 & 13 & 15 & -2 & 606 & 15 & 3 & 12 & 687 & 13 & 9 & 4 \\
\hline Vel'ké Chyndice & 344 & 2 & 8 & -6 & 342 & 11 & 1 & 10 & 325 & 8 & 8 & 0 \\
\hline Vel'ké Zálužie & 3893 & 60 & 28 & 32 & 3974 & 80 & 41 & 39 & 4238 & 59 & 52 & 7 \\
\hline Vel'ký Cetín & 1713 & 12 & 18 & -6 & 1692 & 29 & 7 & 22 & 1545 & 17 & 30 & -13 \\
\hline Vel'ký Lapáš & 1129 & 15 & 16 & -1 & 1171 & 25 & 17 & 8 & 1739 & 105 & 42 & 63 \\
\hline Vinodol & 1852 & 27 & 13 & 14 & 1891 & 23 & 12 & 11 & 2005 & 46 & 53 & -7 \\
\hline Vráble & 9503 & 133 & 131 & 2 & 9470 & 147 & 178 & -31 & 8551 & 140 & 151 & -11 \\
\hline Výčapy-Opatovce & 2133 & 33 & 25 & 8 & 2125 & 23 & 29 & -6 & 2216 & 31 & 36 & -5 \\
\hline
\end{tabular}


Table 1. Cont.

\begin{tabular}{|c|c|c|c|c|c|c|c|c|c|c|c|c|}
\hline \multirow{2}{*}{ Municipality } & \multicolumn{4}{|c|}{ Year 2002} & \multicolumn{4}{|c|}{ Year 2005} & \multicolumn{4}{|c|}{ Year 2020} \\
\hline & 1 & 2 & 3 & 4 & 1 & 2 & 3 & 4 & 1 & 2 & 3 & 4 \\
\hline Zbehy & 2112 & 64 & 48 & 16 & 2171 & 70 & 56 & 14 & 2249 & 50 & 55 & -5 \\
\hline Žirany & 1299 & 20 & 7 & 13 & 1344 & 37 & 20 & 17 & 1351 & 35 & 23 & 12 \\
\hline Žitavce & 369 & 2 & 5 & -3 & 334 & 0 & 13 & -13 & 396 & 5 & 7 & -2 \\
\hline
\end{tabular}

Source: [57]. Legend: 0 -in the given year, the municipality was a part of another seat; 1 -population as of the given year; 2 -immigration; 3-emigration; 4-migration balance.

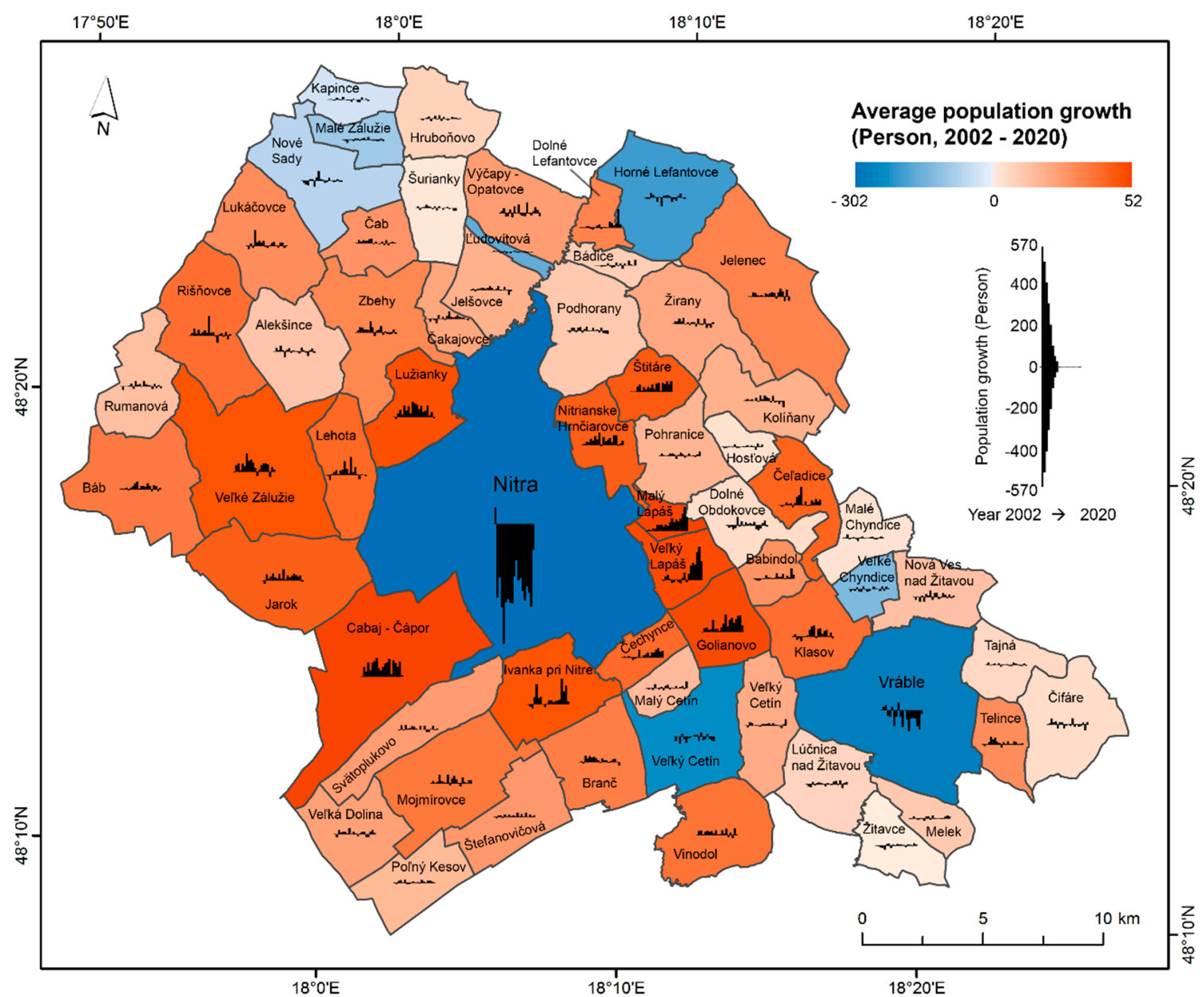

Figure 2. Population growth and decline in the municipalities of the Nitra district between the years 2002 and 2020. Source: [57]. Legend: The small graphs in the cadastres of municipalities represent annual population growth or decline from 2002 to 2020 .

\subsection{Changes in Housing Numbers in the Municipalities of the Nitra District in 2001 and 2011}

If we compare the housing numbers from the two available official materials of the Statistical Office of the Slovak Republic $[58,59]$ for 62 municipalities of the district of Nitra, an increase in housing numbers was recorded in all municipalities, with the exception of the following municipalities: Host'ová, Lúčnica nad Žitavou, Malé Chyndice, Melek, Nová Ves nad Žitavou, Podhorany, Svätoplukovo, Vel'ké Chyndice, Vel'ký Cetín, and Žitavce (Table 2). In the case of the municipality of Podhorany, the decrease in the housing numbers is related to the separation of the municipality of Bádice on 31 December 2002. The highest number of new housing between 2001 and 2011 was naturally recorded in two urban settlements in the district of Nitra, i.e., in the city of Nitra, an increase in flats by 2416 and an increase in houses by 1642 (in total from 35,605 in 2001 to 39,663 in 2011), and in 
the town of Vráble, an increase in flats by 174 and an increase in houses by 77 (in total, from 4230 to 4481). Within rural municipalities, we can see the largest number of new housing in the decade between 2001 and 2011 in the following municipalities: Cabaj-Čápor, Golianovo, Ivanka pri Nitre, Jarok, Lehota, Lužianky, Malý Lapáš, Nitrianske Hrnčiarovce, Rišňovce, Vel'ké Zálužie, Vinodol, and Zbehy. On the contrary, the smallest differences in the total sum of housing between 2001 and 2011 were recorded in the municipalities of Kapince, Klasov, Čifáre, Dolné Lefantovce, Dolné Obdokovce, Hruboňovo, Ludovítová, Malé Zálužie, Rumanová, and Tajná (Table 2).

Table 2. Housing numbers according to the census of population and housing in 2001 and 2011 in the municipalities of the district of Nitra.

\begin{tabular}{|c|c|c|c|c|c|c|}
\hline \multirow{2}{*}{ Municipality } & \multicolumn{3}{|c|}{ Year 2001} & \multicolumn{3}{|c|}{ Year 2011} \\
\hline & Flats & Houses & Total & Flats & Houses & Total \\
\hline Alekšince & 448 & 383 & 831 & 484 & 412 & 896 \\
\hline Babindol & 170 & 160 & 330 & 179 & 170 & 349 \\
\hline Báb & 313 & 312 & 625 & 369 & 344 & 713 \\
\hline Bádice & 0 & 0 & 0 & 103 & 103 & 206 \\
\hline Branč & 591 & 584 & 1175 & 680 & 618 & 1298 \\
\hline Cabaj-Čápor & 1014 & 996 & 2010 & 1086 & 1049 & 2135 \\
\hline Čab & 180 & 177 & 357 & 228 & 204 & 432 \\
\hline Čakajovce & 315 & 312 & 627 & 356 & 322 & 678 \\
\hline Čechynce & 274 & 278 & 552 & 308 & 288 & 596 \\
\hline Čel'adice & 252 & 237 & 489 & 314 & 245 & 559 \\
\hline Čifáre & 203 & 190 & 393 & 209 & 189 & 398 \\
\hline Dolné Lefantovce & 168 & 153 & 321 & 166 & 164 & 330 \\
\hline Dolné Obdokovce & 287 & 289 & 576 & 334 & 291 & 625 \\
\hline Golianovo & 345 & 340 & 685 & 402 & 397 & 799 \\
\hline Horné Lefantovce & 292 & 171 & 463 & 305 & 274 & 579 \\
\hline Host'ová & 111 & 106 & 217 & 106 & 104 & 210 \\
\hline Hruboňovo & 159 & 158 & 317 & 166 & 162 & 328 \\
\hline Ivanka pri Nitre & 648 & 579 & 1227 & 721 & 597 & 1318 \\
\hline Jarok & 517 & 511 & 1028 & 569 & 539 & 1108 \\
\hline Jelenec & 530 & 494 & 1024 & 558 & 523 & 1081 \\
\hline Jelšovce & 277 & 273 & 550 & 300 & 296 & 596 \\
\hline Kapince & 67 & 63 & 130 & 67 & 64 & 131 \\
\hline Klasov & 297 & 296 & 593 & 311 & 283 & 594 \\
\hline Kolíňany & 429 & 415 & 844 & 479 & 447 & 926 \\
\hline Lehota & 520 & 495 & 1015 & 602 & 576 & 1178 \\
\hline Lúčnica nad Žitavou & 310 & 310 & 620 & 303 & 299 & 602 \\
\hline L'udovítová & 56 & 54 & 110 & 58 & 55 & 113 \\
\hline Lukáčovce & 336 & 319 & 655 & 370 & 319 & 689 \\
\hline Lužianky & 710 & 666 & 1376 & 808 & 762 & 1570 \\
\hline
\end{tabular}


Table 2. Cont.

\begin{tabular}{|c|c|c|c|c|c|c|}
\hline \multirow{2}{*}{ Municipality } & \multicolumn{3}{|c|}{ Year 2001} & \multicolumn{3}{|c|}{ Year 2011} \\
\hline & Flats & Houses & Total & Flats & Houses & Total \\
\hline Malé Chyndice & 124 & 122 & 246 & 120 & 115 & 235 \\
\hline Malé Zálužie & 88 & 87 & 175 & 90 & 90 & 180 \\
\hline Malý Cetín & 113 & 106 & 219 & 122 & 113 & 235 \\
\hline Malý Lapáš & 103 & 103 & 206 & 169 & 168 & 337 \\
\hline Melek & 146 & 144 & 290 & 140 & 136 & 276 \\
\hline Mojmírovce & 787 & 748 & 1535 & 815 & 749 & 1564 \\
\hline Nitra & 28,114 & 7491 & 35,605 & 30,530 & 9133 & 39,663 \\
\hline Nitrianske Hrnčiarovce & 528 & 529 & 1057 & 618 & 610 & 1228 \\
\hline Nová Ves nad Žitavou & 429 & 377 & 806 & 430 & 372 & 802 \\
\hline Nové Sady & 413 & 389 & 802 & 436 & 387 & 823 \\
\hline Paňa & 125 & 122 & 247 & 143 & 139 & 282 \\
\hline Podhorany & 441 & 442 & 883 & 336 & 335 & 671 \\
\hline Pohranice & 309 & 301 & 610 & 332 & 315 & 647 \\
\hline Pol'ný Kesov & 183 & 166 & 349 & 205 & 189 & 394 \\
\hline Rišňovce & 548 & 520 & 1068 & 633 & 572 & 1205 \\
\hline Rumanová & 248 & 232 & 480 & 255 & 238 & 493 \\
\hline Svätoplukovo & 396 & 397 & 793 & 396 & 392 & 788 \\
\hline Štefanovičová & 88 & 76 & 164 & 109 & 94 & 203 \\
\hline Štitáre & 163 & 165 & 328 & 203 & 203 & 406 \\
\hline Šurianky & 164 & 159 & 323 & 197 & 164 & 361 \\
\hline Tajná & 94 & 94 & 188 & 101 & 101 & 202 \\
\hline Telince & 79 & 75 & 154 & 105 & 95 & 200 \\
\hline Vel'ká Dolina & 192 & 174 & 366 & 222 & 184 & 406 \\
\hline Vel'ké Chyndice & 115 & 108 & 223 & 102 & 97 & 199 \\
\hline Vel'ké Zálužie & 1042 & 997 & 2039 & 1195 & 1068 & 2263 \\
\hline Vel'ký Cetín & 518 & 512 & 1030 & 514 & 484 & 998 \\
\hline Vel'ký Lapáš & 334 & 329 & 663 & 363 & 353 & 716 \\
\hline Vinodol & 466 & 432 & 898 & 503 & 467 & 970 \\
\hline Vráble & 3026 & 1204 & 4230 & 3200 & 1281 & 4481 \\
\hline Výčapy-Opatovce & 592 & 581 & 1173 & 649 & 611 & 1260 \\
\hline Zbehy & 618 & 603 & 1221 & 661 & 645 & 1306 \\
\hline Žirany & 382 & 338 & 720 & 406 & 368 & 774 \\
\hline Žitavce & 135 & 132 & 267 & 135 & 129 & 264 \\
\hline
\end{tabular}

Source: $[58,59]$. Legend: 0 -in the given year, the municipality was a part of another seat.

\subsection{Suburbanization Processes in the Municipalities of the District of Nitra in 2002 and 2020}

In the municipalities of the district of Nitra, five suburbanization processes were monitored - the expansion of settlements or housing developments, industrial areas, transport facilities, agricultural areas (currently complemented by industrial production), and other areas (wastewater treatment plants (WWTPs), transformer stations, landfills, and collection yards) - which have changed the area of the original landscape elements in the structure of municipalities. After processing the changes in the area due to these processes, 
we divided the municipalities into the following five categories for the period of 2002 to 2020: (1) more than 100.00 ha; (2) 50.00 to 99.99 ha; (3) 25.00 to 49.99 ha; (4) 10.00 to 24.99 ha; (5) up to 9.99 ha.

The first category (change of area over 100.00 ha) includes the city of Nitra and the municipality of Lužianky. In Nitra, the area changed by 694 ha, which represents $6.91 \%$ of the total area of the city; in Lužianky, it changed by 415 ha (33.50\% of the municipality) due to the construction of housing and industrial areas. The most significant construction in the area included the start of construction in the industrial production park of Jaguar Land Rover in 2018. The category of changes from 50.00 to 99.99 ha includes five municipalities (Cabaj-Čápor, Zbehy, Nitrianske Hrnčiarovce, Malý Lapáš, and Mojmírovce), with the process of construction of residential buildings being the biggest change. The largest change in terms of area was recorded in the municipality of Malý Lapáš, where a total of 52.69 ha ( $16.39 \%$ of the municipality) was affected by the suburbanization process (especially by the expansion of residential development). The town of Vráble and nine rural municipalities (Ivanka pri Nitre, Vel'ký Lapáš, Pohranice, Štitáre, Lehota, Svätoplukovo, Golianovo, Rišňovce, Žirany) were included in the category of changes from 25.00 to 49.99 ha. In these municipalities, three suburbanization processes were significantly represented-the expansion of residential developments, industrial areas, and other areas. The most significant changes were observed in the municipality of Ivanka pri Nitre (a total of 48.38 ha, which represents $3.25 \%$ of the area of the municipality). In the municipality of Pohranice, in addition to the construction of residential buildings (an increase of $16.19 \mathrm{ha}$ ), industrial objects (an increase of $5.93 \mathrm{ha}$ ) and transport facilities (10.92 ha) were also included among the new significant elements. In the municipality of Žirany, residential buildings and industrial areas changed their area by approximately the same amount, i.e., by more than 12.00 ha. In the municipalities of Svätoplukovo and Rišňovce, the expansion of settlements or housing developments occurred in the period from 2002 to 2020 as the only type of suburbanization process $(100.00 \%)$; the other types of suburbanization processes had no representation in the emerging suburbanization. The category of changes from 10.00 to 24.99 ha includes 27 municipalities (Jarok, Výčapy-Opatovce, Jelenec, Čakajovce, Vel'ké Zálužie, Jelšovce, Alekšince, Dolné Lefantovce, Babindol, Lukáčovce, Rumanová, Čab, Kolíñany, Host'ová, Dolné Obdokovce, Podhorany, Báb, Klasov, Štefanovičová, Šurianky, Čel'adice, Čechynce, Lefantovce, Nové Sady, Branč, Hruboňovo, and Vel'ký Cetín). In all these municipalities, except for the municipality of Čakajovce, the change in area mainly included the new construction of residential buildings. In some of these municipalities, the new construction of residential buildings was the only type of urbanization process (100.00\%): Podhorany, Štefanovičová, and Šurianky. In the municipality of Čakajovce, the urbanization process of construction of industrial objects (a change to $9.85 \mathrm{ha}$ ) had a more significant impact in comparison with the added areas of residential or housing developments ( $8.10 \mathrm{ha}$ ) and the construction of transport facilities (2.94 ha), especially in the vicinity of the Nitra-North industrial park. Most housing objects were added to the municipalities of Výčapy-Opatovce (19.69 ha) and Jelenec (19.41 ha). The last category of changes up to 9.99 ha includes 18 municipalities (Vel'ká Dolina, Bádice, Vinodol, Malý Cetín, Melek, Pol'ný Kesov, Nová Ves nad Žitavou, Čifáre, Malé Chyndice, Lúčnica nad Žitavou, Žitavce, Paňa, Tajná, L'udovítová, Malé Zálužie, Telince, Vel'ké Chyndice, and Kapince; Figure 3). The highest number of housing projects was added in the municipality of Vel'ká Dolina (area 9.40 ha); on the contrary, the smallest changes in the expansion of areas related to settlements or housing developments were recorded in the municipality of Kapince (0.37 ha). This category includes the most municipalities (10 municipalities), with the occurrence of only one process of suburbanization - the construction of housing (100.00\%; Vel'ká Dolina, Melek, Nová Ves nad Žitavou, Čifáre, Lúčnica nad Žitavou, Žitavce, L'udovítová, Malé Zálužie, Telince, and Vel'ké Chyndice). Our obtained results confirm Hypothesis 2. 


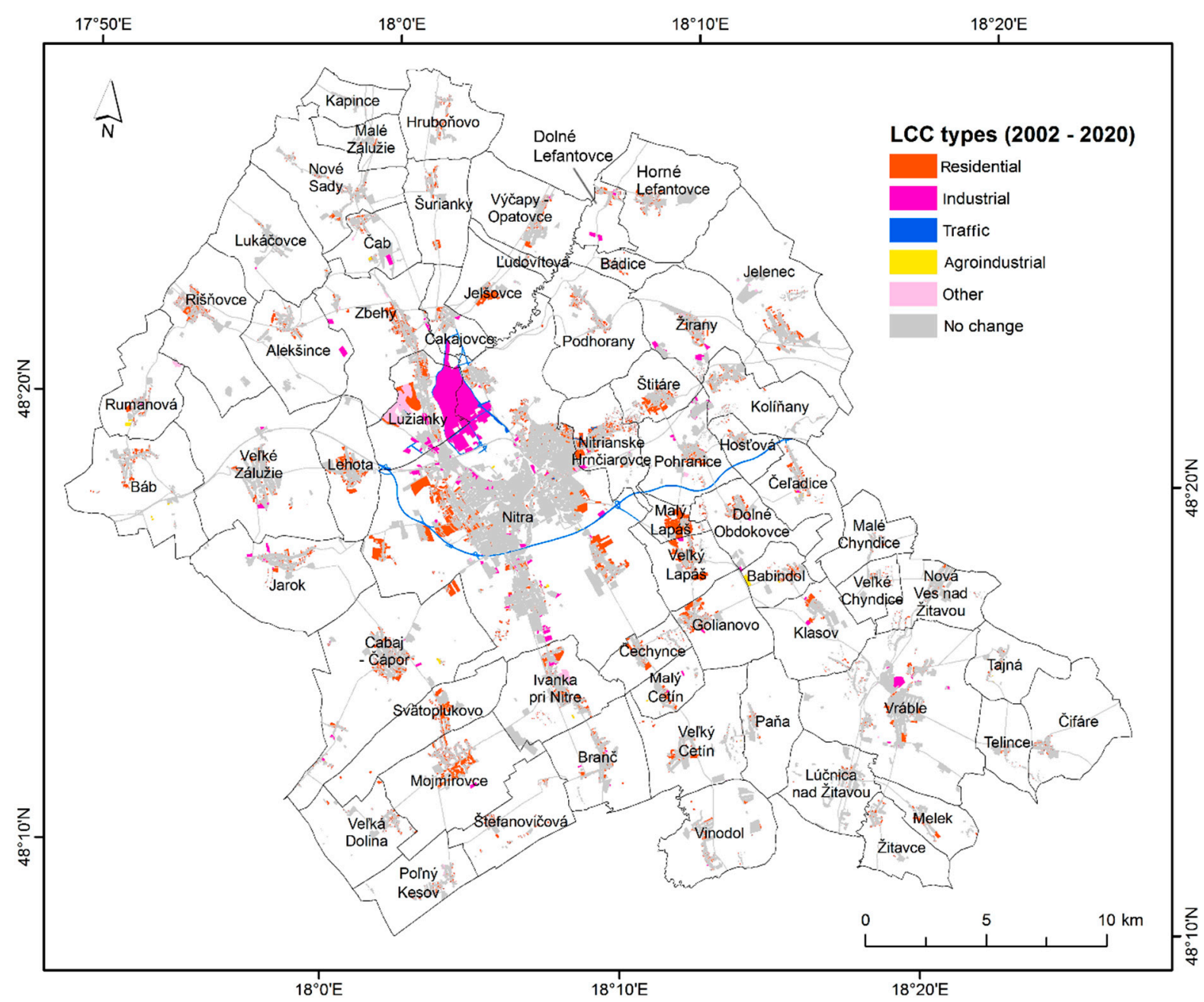

Figure 3. Spatial distribution of changes in landscape structure related to suburbanization in the municipalities of the Nitra district in 2002 and 2020. Legend: LCC-land cover changes.

In all municipalities except for Lužianky (Figure 4), the most significant process in terms of area was the expansion of settlements or housing developments. Hypothesis 4 is confirmed by our results. In 15 municipalities, it was the only process of area change, and in 5 municipalities, this change accounted for more than $99 \%$. The municipalities with the largest share of changes with respect to the total area of the municipality include the municipality of Lužianky (the change affected $33.50 \%$ of the municipality) and the municipality of Malý Lapás (the change affected $16.39 \%$ of the municipality). On the contrary, the smallest area changes (less than $0.50 \%$ of the area) were recorded in nine municipalities (Kapince, Vel'ké Chyndice, Telince, Malé Zálužie, Tajná, Paňa, Žitavce, Lúčnica nad Žitavou, and Čifáre; Figures 3 and 4). These are villages on the outskirts of the district of Nitra. The farthest from the city of Nitra, in the northern part of the district, are the municipalities of Kapince and Malé Zálužie; the other municipalities form a "newly emerging suburbanization ring" around the town of Vráble.

When comparing municipalities in terms of existing developments and new (expanding) developments, the city of Nitra has a dominant position. During the monitored period, the built-up area covered 2662.50 ha, of which the new developments are located on an area of 694.00 ha. The second-largest increase was recorded by the municipality of Lužianky, with a total increase of 552.34 ha, of which new developments cover an area of 415.97 ha. The most built-up municipalities include Cabaj-Čápor (224.44 ha), the town of Vráble (365.24 ha), Ivanka pri Nitre (194.02 ha), and Vel'ké Zálužie (185.68 ha). 


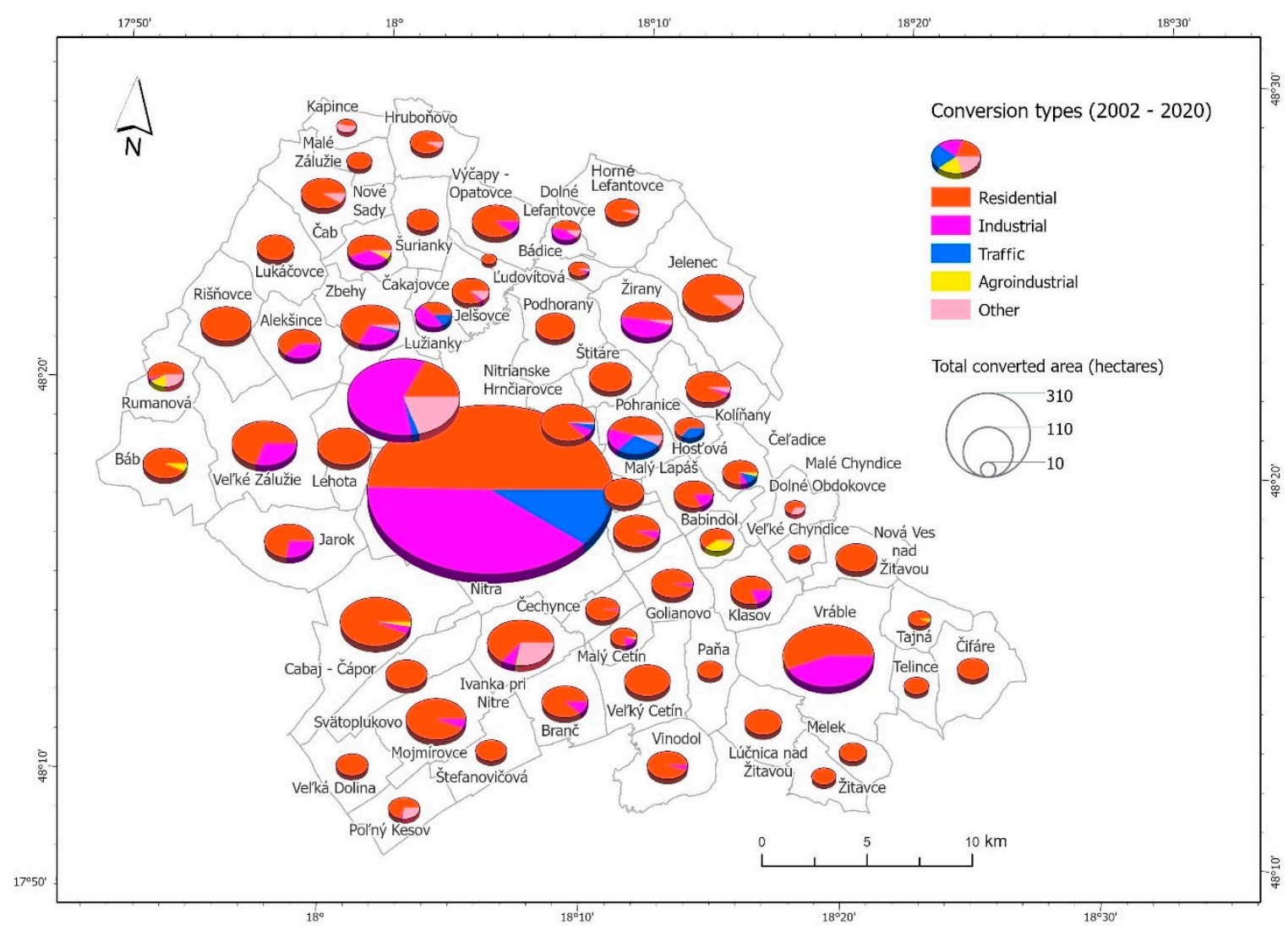

Figure 4. Type of landscape structure changes and its share of the total area of changed areas in the municipalities of the Nitra district in 2002 and 2020.

\subsection{Suburbanization Processes in the Municipalities of the Nitra District in 2002 and 2005}

We also evaluated changes in the landscape structure related to suburbanization processes that occurred in the municipalities of the Nitra district in the period of 2002 and 2005. Data from the comparison of changes within these two years in the vast majority of municipalities in the district of Nitra show minimal or relatively small changes compared to those occurring between 2002 and 2020 or 2005 and 2020, which is comparably higher. Hypothesis 3 is confirmed by our results. Based on the obtained results, we divided the municipalities of the Nitra district into the following four categories, according to the total area of urbanization processes: (1) 10.00 ha and more; (2) 1.00-9.99 ha; (3) 0.01-0.99 ha; (4) no change. The city of Nitra itself belongs to the first category. The processes related to suburbanization from their total area $(29.17 \mathrm{ha})$ included mostly changes related to the expansion of settlements or residential developments (19.43 ha, 66.61\%), industrial areas ( $8.26 \mathrm{ha}, 28.32 \%$ ), and other areas (1.48 ha, 5.07\%). Again, Hypothesis 4 is confirmed by our obtained results. These changes were mainly happening on the outskirts of the city. The processes of expanding traffic areas and agroindustrial areas did not appear in the city of Nitra among the changes in 2002 and 2005. According to the results, we include 17 rural municipalities in the second category (Lužianky, Čab, Branč, Báb, Jelšovce, Rišňovce, Babindol, Kolíňany, Cabaj-Čápor, Jarok, Vel'ké Zálužie, Lehota, Pohranice, Vel'ký Cetín, Nitrianske Hrnčiarovce, Čechynce, and Zbehy) and the second town seat in the district of Nitra (town of Vráble). In six municipalities of this category, settlement construction $(100.00 \%)$ was the main and only suburbanization process (Rišňovce, Kolíňany, Vel'ké Zálužie, Lehota, Nitrianske Hrnčiarovce, and Zbehy) in the change of landscape structure between 2002 and 2005. The same applied to another five municipalities, where residential development had a dominant position (90.01-99.99\%) but in interaction with another subrbanization process, i.e., the expansion of agroindustrial or industrial areas. In the municipalities of Lužianky 
and Čab and in the town of Vráble, the expansion of industrial areas had a dominant impact (Lužianky $88.37 \%$; Čab 99.84\%; Vráble 78.31\%). In the municipality of Cabaj-Čápor. it was the expansion of agroindustrial areas (43.89\%), and in the village of Pohranice, it was the expansion of other areas (55.92\%). Of the 18 municipalities included in the second category, changes related to suburbanization processes affected the municipalities of Čab $(0.79 \%)$, Lužianky $(0.55 \%)$, and Babindol $(0.49 \%)$ the most. In the other 15 municipalities, suburbanization processes affected only a small area of their total area $(0.05-0.33 \%)$. The third category includes 39 municipalities with minimal area changes of the landscape structure (0.02-0.98 ha) in 2002 and 2005 that are related to any of the suburbanization processes. The vast majority of these municipalities (34 municipalities) had a 100.00\% share in the expansion of residential developments (Mojmírovce, Svätoplukovo, Čifáre, Lefantovce, Malý Lapáš, Ivanka pri Nitre, Hruboňovo, Jelenec, Nové Sady, Štitáre, Vel'ký Lapáš, Čakajovce, Čel'adice, Šurianky, Alekšince, Bádice, Malý Cetín, Pol'ný Kesov, Paňa, Nová Ves nad Žitavou, Rumanová, Klasov, Telince, Host'ová, Malé Chyndice, Lúčnica nad Žitavou, Vel'ké Chyndice, Tajná, Vel'ká Dolina, Žitavce, Malé Zálužie, Žirany, Melek, and Štefanovičová). In the other three municipalities (Golianovo, Lukáčovce, Vinodol) the changes were related mainly to the expansion of settlement development but also in combination with the expansion of other suburbanization processes, especially industrial areas and other areas. In the village of Dolné Obdokovce, as the only village in this category, $100.00 \%$ share was attributed to the effect of expanding industrial areas, but only on an area of $0.03 \mathrm{ha}$, which only minimally reflected the total area of the village. In the municipality of Kapince, changes in the landscape structure were influenced by the expansion of other areas $(62.50 \%)$ and settlement or residential development $(37.50 \%)$. The last and fourth category includes only four municipalities of the district of Nitra (Dolné Lefantovce, L'udovítová, Podhorany, Výčapy-Opatovce), in which the comparison of years 2002 and 2005 showed no changes related to any of the suburbanization processes.

\section{Discussion and Conclusions}

Suburbanization can be defined as a process manifested in changes in the environment and society. There is no doubt that suburbanization has significant economic, territorial, transport, social, cultural, political, infrastructural, and environmental consequences [19]. Nowadays, urbanization is no longer typical for the growth of cities or towns only but influences the processes in the rural countryside as well. The actual changes of landscapes are induced by urbanization processes such as residential or industrial land development and new communication infrastructures. These processes are mainly controlled by social and economic factors that exceed the local conditions [62]. The direct impact of suburbanization is the conversion of land from farming to suburban uses [2]. Suburbanization can also disrupt and alter the landscape features of agricultural land into building plots [63]. Within the areas affected by the suburbanization process, the proportion of agricultural land is generally reduced, while land for housing and related services for residents and industrial use increases [64]. The growth of European cities in recent years has occurred primarily on former agricultural land. Typically, urban development and agriculture compete for the same land, as cropland adjacent to existing settlements is ideal for urban expansion [65].

The Richmond, Virginia region is an example of a suburbanization area in the 20th century. For suburbanization in this area, new residential settlement sites were searched for in the more remote yet easily accessible countryside. Smaller surrounding towns and villages were preferred. Rural areas lost much of their farmland [66]. Suburbanization processes around the towns of Nitra and Vráble in the district Nitra are evolving in a similar fashion. Suburbanization represents one of the most important contemporary problems these towns are facing. It is mainly a transformation of the spatial redistribution of the population from towns to the surrounding villages for various socioeconomic reasons. Such an example are the cities of the Nitra district. The population changes of the town of Nitra have recorded a negative balance-with a decrease of about 10,775 inhabitants between the years 2002 and 2020. A decrease in population was also recorded in the town 
of Vráble (from 9503 in 2002 to 8551 in 2020; Table 1). A migration of the population to the countryside has occurred. These results confirm Hypothesis 3.

Political changes in Slovakia after 1989 initiated new economic trends that have significantly affected the structure of cities and rural municipalities. The process of suburbanization has changed the rural landscape, with a widespread increase in new residential areas. Currently, an expansion of construction is taking place in the Slovak countryside. This construction often brings about very inadequate housing types, disregarding the urban layout [14]. For more than a decade, the European Union has recognized "soil" as a common good and considers it a finite resource of inestimable value. One of the main threats associated with human activity is the consumption of land, which is perceived as a "change of land cover from natural to artificial" [67].

In September 2006, the European Commission adopted a Thematic Strategy for Soil Protection. According to the European Commission, soil degradation is a serious problem in Europe. It is driven or aggravated by human activity, such as inadequate agricultural and forestry practices, industrial activities, tourism, urban and industrial spread, and construction works. These activities have a negative impact and prevent the soil from performing its broad range of functions and services to humans and ecosystems. This results in the loss of soil fertility, carbon, and biodiversity, a decrease in water-retention capacity, disruption of gas and nutrient cycles, and reduced degradation of contaminants. The overall objective of this strategy is the protection and sustainable use of soil [68]. In 2012, the European Commission complemented the existing strategy with guidelines on best practices for reducing, mitigating, or compensating for land development. In the subchapter of these guidelines, titled 4.4. The protection of agricultural land and valuable land, Slovakia is mentioned in connection with the collection of fees for the change of use of agricultural land in order to prevent further land-grabs and the development of the best agricultural land [69].

Nevertheless, the impact of suburbanization processes in the municipalities of the district of Nitra has manifested itself in recent years, with significant changes in their landscape structure. Overall, the suburbanization process between 2002 and 2020 was reflected in the expansion of settlements or residential developments on an area of 1366.99 ha, which is up to $60.15 \%$ of all processes. The process of expansion of industrial areas covered an area of 666.18 ha ( $29.31 \%$ of all processes), the process of expansion of transport facilities affected an area of 98.98 ha ( $4.35 \%$ of all processes), the expansion of agroindustrial areas affected 16.61 ha $(0.73 \%$ of all processes), and expansion of other areas was reflected by an area of 124.06 ha (5.46\% of all processes). These results confirm Hypothesis 2 (Figure 5).

If we were to assess the district of Nitra as a whole, in terms of changes related to suburbanization in the two time comparisons, i.e., between 2002 and 2005 and between 2002 and 2020, we could say that the existing suburbanization processes between 2002 and 2005 did not reach the dimensions of the changes that occurred as a result of suburbanization processes between 2002 and 2020 or between 2005 and 2020. These results confirm Hypothesis 3 . The total area affected by some of the suburbanization processes totaled 92.52 ha between 2002 and 2005 and 2272.82 ha between 2002 and 2020, which is an increase of 2180.30 ha in 2020 compared to 2002 (an increase of 2356.57\%). In these two time comparisons, the following suburbanization processes had a dominant influence: (1) settlement or residential development, from 62.97 to 1366.99 ha (an increase of $2070.86 \%$ ); (2) industrial areas, from 25.71 to 666.18 ha (an increase of $2491.13 \%$ ); (3) other areas, from 2.51 to 124.06 ha (an increase of $4842.63 \%$ ); (4) traffic areas from 0.00 to 98.98 ha-related mainly to the construction of the R1 Pribina expressway (Pohranice, Nitra, Nitrianske Hrnčiarovce, Vel'ký Lapáš, Host'ová, Kolíňany, Čel'adice, and Lehota) and the construction of roads around the Nitra-North industrial park, especially in the vicinity of the Jaguar Land Rover plant (municipalities Nitra-Dražovce, Lužianky, Čakajovce, Zbehy); (5) agroindustrial areas from 1.33 to 16.61 ha (especially in the village Babindol by 6.54 ha (greenhouses for growing tomatoes), and in other villages, e.g., Rumanová, Nitra, Cabaj-Č́por, Tajná, Malý Cetín, Ivanka pri Nitre, Čab, and Báb; Figure 5). 

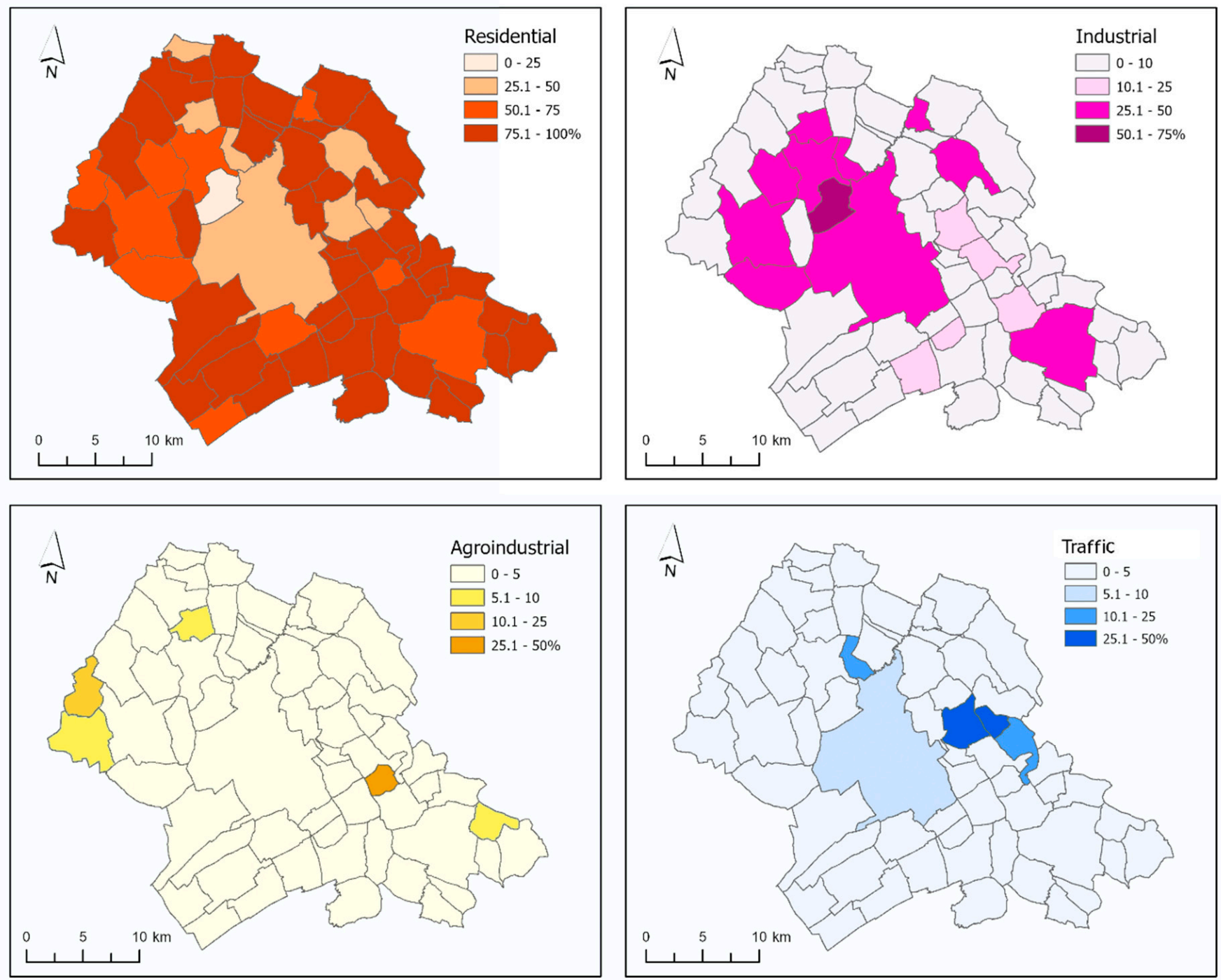

Figure 5. Categories of percentage share of selected suburbanization processes in the municipalities of the Nitra district in 2002 and 2020.

In the surrounding areas of the towns of Nitra and Vráble, new territorial developments are being created, which are reflected in the construction of new residential zones in the peripheral parts of these towns in a ring formation. Around the city of Nitra are, for example, the villages of Malý Lapáš, Vel'ký Lapáš, Nitrianske Hrnčiarovce, Štitáre, Lužianky, Lehota, and Zbehy, and in the vicinity of the town of Vráble, are the villages of Klasov, Nová Ves nad Žitavou, Lúčnica nad Žitavou, Melek, Tajná, Telince, and Žitavce.

Most people moving to suburban municipalities seek to enhance their quality of life [13]. The stimuli for the movement of the population to suburban areas and villages are primarily driven by efforts to improve the quality of life [70]. The urban lifestyle is gradually spreading to small and remote rural settlements. When immigrants from a nearby town spread more loosely into the countryside, they change the traditional lifestyle there and make the distinction between urban and rural lifestyles very diffused [62]. The population growth of the majority of the Czech rural areas is combined with a rapid change in the rural labor market and the low social importance of agriculture for rural development. Economically, in many cases, rural areas depend more on industry [35]. In many villages of the Nitra district, the original agricultural activity in the countryside and the social significance of agriculture have lost their significance. In several villages, we found devastated and abandoned agricultural farms (e.g., Nitrianske Hrnčiarovce, Vel'ké 
Chyndice, Lúčnica nad Žitavou, Vráble, and Telince), which functioned mainly in the period of socialism and then for a short period at the end of the 1990s.

Suburbanization is strongly related to the desire of individuals to live in single-family houses in an attractive "rural" environment. However, it is very unlikely that the post-1990 suburbanization of countries of former communist blocs can be solely attributed to this single factor. It seems more likely that the political and economic transformations have shaped the favorable conditions of the housing market, allowing people to leave the city for the surrounding countryside and contributing to suburbanization in many respects [8]. Suburbanization has always been connected to the construction of single-family homes [71].

One important element of urbanism is the examination of the impact of the location of new developments on existing buildings [72]. We could easily apply this statement to rural municipalities in the district Nitra. So far, they have been characterized by their agricultural landscape with typical rural construction, which, in recent years, has been significantly replaced by the construction of modern family houses; these are atypical and non-standard for the given type of landscape.

The newly built houses are often surrounded by fences that resemble fortified walls, which lead to the isolation of the population. Building developments are concentrated in locations further away from the city. New projects have been prepared for the construction of small houses. Mortgage subsidies and cheaper land in rural areas have become incentives for city dwellers to buy their own houses with a garden. Villages have become the location for the construction of several new residential areas, which are subject to current trends (building houses on small lots, dense built-up areas, cul-de-sacs, and private roads) [14]. The landscape character of the suburbanized areas is greatly influenced by the new construction, its architectural design, and the incorporation of new buildings into the present landscape layout [15].

The consequences of building developments in the municipalities have a territorialspatial character. It is a widespread expansion of the city into the surrounding countryside ("urban boom"), which causes the occupation of agricultural land, loss of characteristic landscape image, creation of a chaotic, amorphous "settlement slurry", the gradual growth of historically created independent rural units with an urban structure, and the gradual disappearance of the identity of the original rural environment by the creation of territorial barriers (inaccessible, fenced neighborhoods of family houses). Economic efficiency will be reflected in the construction of intensive forms of family houses, with the increased density of buildings (Figure 6) and a minimum width of public roads. Infrastructure impacts include the absence of civic amenities, work and leisure facilities, lack of quality public and semipublic spaces of different hierarchies and with various functional uses, and insufficient capacity of transport and technical infrastructure, with the effect of undesired tension in the area. The social impacts are manifested by the mixing of original ("indigenous") residents and new inhabitants ("immigrants"), with the new inhabitants either becoming part of the local community, participating in community life, or separating and forming a disparate group that establishes a distance from the original residents and always tends to be more inclined to the city center. It is a consequence of their lifestyle, which is different from the requirements of domestic residents [73]. 


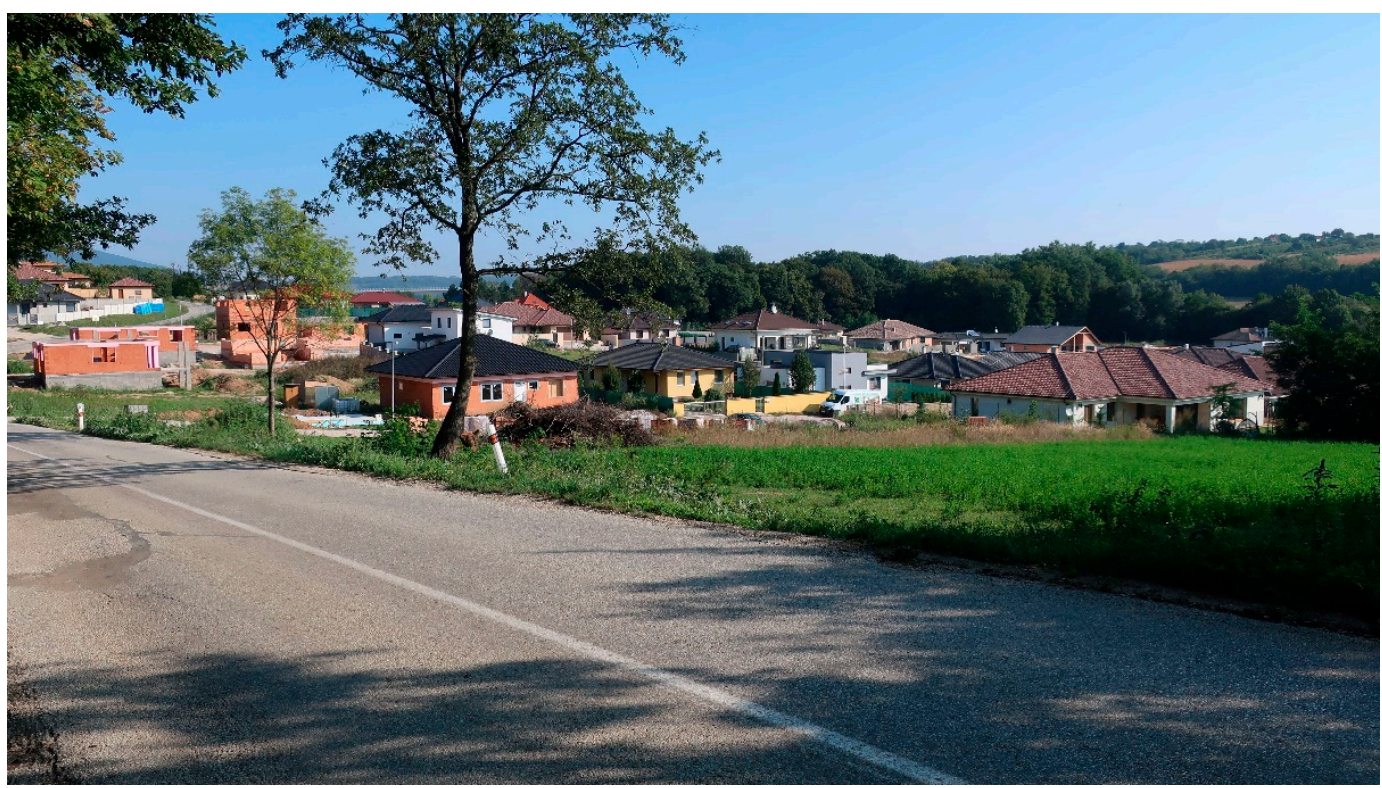

Figure 6. Typical rural development of family houses expanding at the expense of agricultural land in the municipality of Malý Lapáš (Photo: 9 July 2018).

Extensive construction of family villas is connected with the expansion of municipalities, an improvement of their civic amenities, and the reconstruction of transport hubs and roads. However, these facts threaten the very essence of this countryside as a rural area. Some mixture of urban and rural elements, losing their original identity, has been created. Villages depend on commuting to centers for jobs and services [34]. The occurrence of some elements of social infrastructure may provide the inhabitants of the municipalities of the Nitra district with better quality housing in a rural environment. However, in the case of commuting, people satisfy many of their demands for services in places where they work, while the places where the people live lose customers [35]. Selected cultural facilities (theaters, cinemas, museums, galleries) are not located in any of the rural municipalities, except for two cities (Nitra and Vráble). In the total number of municipalities in the Nitra district (62), individual elements of social infrastructure are represented by the following share: only $3.23 \%$ of municipalities in the Nitra district have selected cultural facilities (theaters, cinemas, museums, galleries), playgrounds (especially football; $93.59 \%$, missing only in the municipalities of L'udovítová, Malý Cetín, Telince, Vel'ké Chyndice), schools-especially kindergartens and primary schools $(87.10 \%$, missing in eight municipalities: Bádice, Kapince, Ĺudovítová, Malé Chyndice, Malé Zálužie, Štefanovičová, Telince, Žitavce), post offices (64.52\%, missing in 22 municipalities of the district), libraries $(72.58 \%$, missing in 17 municipalities of the district), grocery stores $(96.77 \%$, missing only in two municipalities: L'udovítová and Štefanovičová), health center (33.87\%-located only in 21 municipalities), pharmacies (35.48\%, missing in 40 municipalities of the district), restaurants $(91.94 \%$, missing in five municipalities: Bádice, Kapince, L'udovítová, Malé Zálužie and Malý Lapáš), and petrol stations $(12.9 \%$, only in eight municipalities: Báb, Cabaj-Čápor, Čakajovce, Dolné Lefantovce, Ivanka pri Nitra, Nitra, Vráble, and Zbehy). The social infrastructure is, of course, predominantly represented in the district town of Nitra and the second town seat of Vráble. Among the rural municipalities in the Nitra district, the most significant in terms of social infrastructure are the following municipalities: Alekšince, Cabaj-Čápor, Ivanka pri Nitra, Lužianky, Mojmírovce, Výčapy-Opatovce, and Zbehy. On the contrary, the social infrastructure is significantly absent in the municipalities of L'udovítová, Telince, Bádice, Štefanovičová, and Kapince [74,75].

New residential developments taking over of the interspace have various territorial forms, which can be divided into point formations, i.e., residential satellites scattered in the open landscape, the so-called "neighborhoods outside the city" or "dormitories", with the 
development of visually similar houses along narrow access roads, without accompanying vegetation and parking, with the absence of public spaces or basic civic amenities, which replace the surrounding settlements or the core town (Párovské Háje, Kynek); linear formations as a consequence of the growth of originally territorially independent rural settlements into a compact unit along main transport routes and the establishment of a continuous built-up urban structure (these do not occur in the district of Nitra); ring formations, representing the wrapping or gradual stage ring encirclement, construction around the existing rural structure with new construction in localities located in contact with the built-up area when resolving functional and operational links to the original development (the surroundings of the city of Nitra and Vráble). Farmland loss has been extremely rapid in some villages of the Nitra district. The results of our study clearly show the dynamic growth of built-up areas over the past 15 years.

A change in the rural character of municipalities because of the construction of urbantype houses is perceived as being very problematic. Another serious problem is the insufficient capacity of technical infrastructures such as sewerage and wastewater treatment. The costs of ensuring the quality of the environment and of public spaces, which are, in many cases, beyond the economic possibilities of municipalities, are also increasing significantly [15].

From the environmental point of view, we can consider the main problem of emerging suburbanization in the municipalities of the district of Nitra to be the quantitative decrease (taking over) of quality agricultural land for construction related to suburbanization, especially for the construction of settlements or residential developments. The consequences of increasing the total population in rural municipalities also include several environmental problems, which subsequently pose issues for the administration of these municipalities, e.g., insufficient environmental and social infrastructure of municipalities, problems with the connection of the population to public water supply and sewerage, the increasing production of municipal waste, and heavy traffic. There is a permanent decline in agricultural land and an increase in built-up areas.

One of the reasons for the development of suburbanization in the municipalities of the district of Nitra can be seen in the economic growth and expansion of industrial production ("industrial boom") in the industrial zones on the outskirts of Nitra (parts of Mlynárce, Dražovce, and Dolné Krškany) and neighboring municipalities (e.g., Lužianky, Zbehy, Ivanka pri Nitre). In the established industrial operations within the industrial zones of Nitra-South and Nitra-North (I. and II.), the number of job opportunities is growing, which directly affects the increasing employment of the economically active population not only from the city of Nitra but also from the surrounding municipalities.

The Nitra-North industrial zone (on an area of $240 \mathrm{ha}$ ) employs approximately $5000 \mathrm{em}$ ployees $[76,77]$. The Nitra-South industrial zone is intended mainly for domestic small- and medium-sized enterprises ( $3 \mathrm{ha}$ ) and, at the same time, as a science and technology park of the German company Muehlbauer Technologies (5 ha). At present, about 150 employees have found employment here, but with the plan to expand this zone, a further increase in employees is expected. The oldest industrial park, not only in the district of Nitra but in the whole of the Slovak Republic, is the industrial park of the town of Vráble, which was established in the district of Nitra in 1995 and currently occupies an area of more than 20 ha. In total, six companies have been established in the industrial park, which employs about 2200 people, with another 1500 people working in the wider industrial zone. Another industrial park, which has been expanding in the district of Nitra in recent years, on an area of $74.13 \mathrm{ha}$, is the Čab industrial zone, currently with approximately 800 employees [76,78]. The growing number of employees can be seen in the example of the Slovak plant-Jaguar Land Rover Slovakia (as part of the British carmaker Jaguar Land Rover) - which is located on the border of the city of Nitra (part of Dražovce) and Lužianky and Zbehy, on an area of about 30 ha (Figure 7). When production started in 2018, the plant had 1300 employees; in 2019, this number increased to 2200 and, currently, the plant employs more than 3000 employees, with plans for a further increase. This process was 
pushed forward in July 2020 by obtaining a permit to expand production in order to ensure the production of 300,000 vehicles per year from the current level of 150,000 vehicles (2018). The expansion of the plant (by another approx. $12 \mathrm{ha}$ ) will also mean an increase in the demands of the workforce [79].

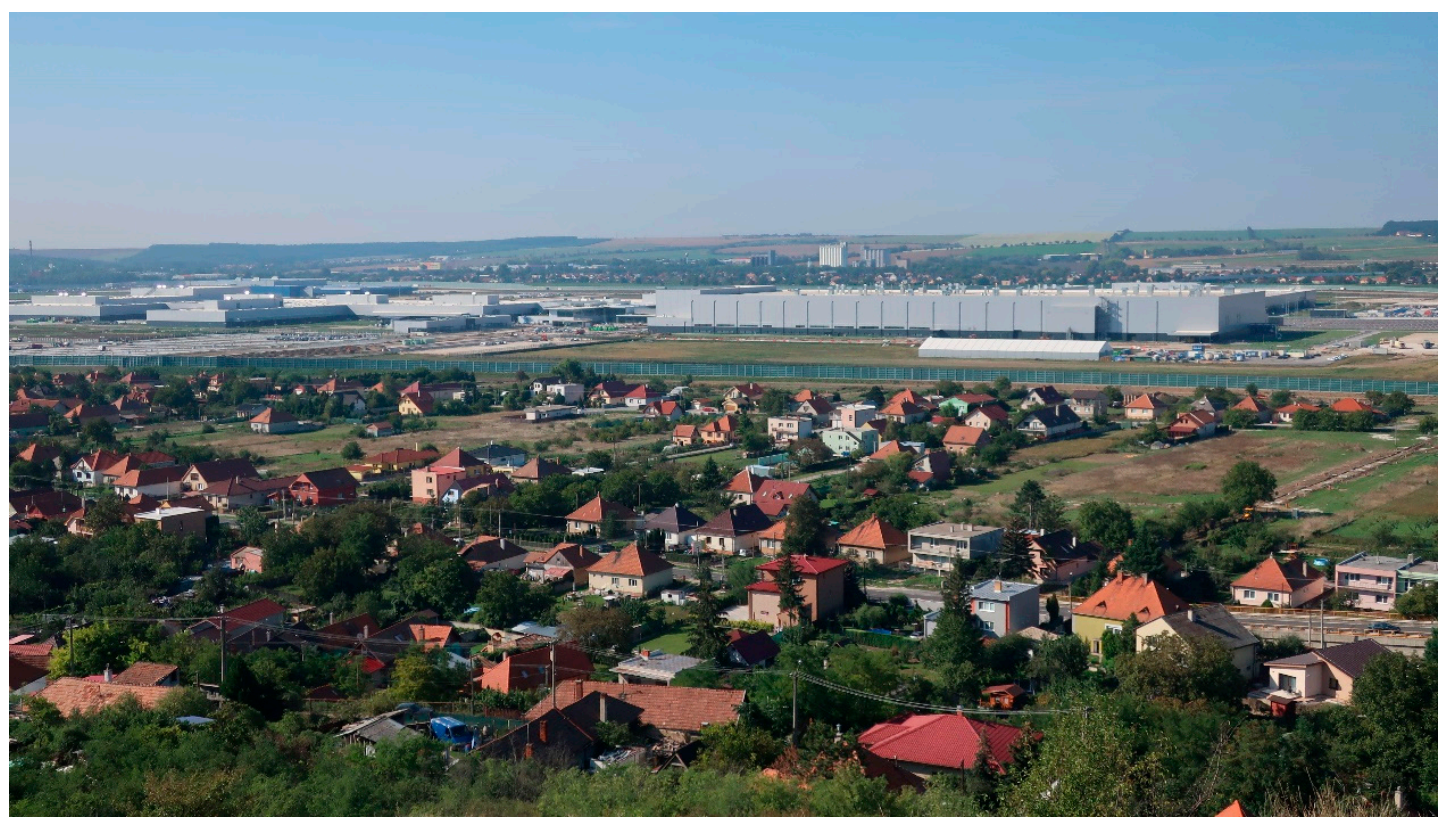

Figure 7. Newly constructed complex of the Jaguar Land Rover factory on a former agricultural land close to the village of Dražovce, which is a suburban part of the city of Nitra (Photo: 9 October 2018).

Residential suburbanization, manifested by intensive construction traffic in the suburban zone, contributes to significant changes in the morphology of suburban villages [9]. Accessibility becomes the most important factor in the changes in the landscape; even in the remote countryside, suburbanization processes can be observed if the municipalities of the district of Nitra are accessible by transport. Industrial zones are directly connected to the Pribina R1 expressway (commissioned in 2011) or 1-st classroads, which simplifies the availability of employees from more distant municipalities. With the construction of the R1 Pribina expressway and the subsequent relief of 1-st classroad I/65 (Zlatomoravecká cesta), use of 1-st class road I/64, in the direction of Nitra-Nové Zámky, and its completion in the direction of Nitra-Topol'čany, many municipalities have become well-accessible and directly connected to the city of Nitra, which fulfill all the functions of the core city. On the contrary, 1-st class road I/51 (Nitra-Levice), connecting the villages of Malý and Vel'ký Lapáš, Babindol, and Klasov and the town of Vráble, has become risky and considerably busier in terms of transport. These results confirm Hypothesis 5 because suburbanization processes are most pronounced in municipalities in the vicinity of the most important socioeconomic factors (industry and the commissioned Pribina R1 expressway) operating in the district of Nitra.

The perception of property attractiveness is determined by price-setting attributes such as building standard, area, utilities, zoning, and also location and neighborhood. The attractiveness of residential property is manifested in its market value [80]. Construction in the surrounding villages is also significantly affected by the price of land. According to real estate websites (e.g., pozemky.sk or topreality.sk), prices for land in the city of Nitra range from 80 to 191 EUR (excluding land prices in predominantly industrial local areas such as Horné and Dolné Krškany). The most expensive pieces of land are the land plots intended for the construction of houses in the local part of Zobor (prices from 88.62 to $191.72 \mathrm{EUR} / \mathrm{m}^{2}$ ), Párovské Háje (prices from 98.41 to $108.31 \mathrm{EUR} / \mathrm{m}^{2}$ ), Kynek (prices from 116.20 to $131.47 \mathrm{EUR} / \mathrm{m}^{2}$ ), Čermán̆ (prices in the range of 151.28 to 
171.25 EUR $/ \mathrm{m}^{2}$ ), Janíkovce (prices from 97.05 to $118 \mathrm{EUR} / \mathrm{m}^{2}$ ), and Mlynárce (approx. 123.49 EUR $/ \mathrm{m}^{2}$ ). The surrounding municipalities, neighboring the city of Nitra, also have expensive land, e.g., Nitrianske Hrnčiarovce (from 84.04 to $180 \mathrm{EUR} / \mathrm{m}^{2}$ ), Cabaj-Čápor (from 55 to $76.21 \mathrm{EUR} / \mathrm{m}^{2}$ ), and Malý Lapás (73 to $95 \mathrm{EUR} / \mathrm{m}^{2}$ ). The high price of land can also be seen in the municipality of Ivanka pri Nitre (approx. $81.22 \mathrm{EUR} / \mathrm{m}^{2}$ ), Lehota (approx. 90 to $106 \mathrm{EUR} / \mathrm{m}^{2}$ ), Pohranice (approx. $88 \mathrm{EUR} / \mathrm{m}^{2}$ ), Štitáre (approx. 78 to $98 \mathrm{EUR} / \mathrm{m}^{2}$ ), and Svätoplukovo, Golianovo, Čakajovce, and Šurianky, where the prices range from about 55 to $64 \mathrm{EUR} / \mathrm{m}^{2}$. These municipalities have a good connection to the road network. Land prices are decreasing in the municipalities away from the city of Nitra, with III.-class roads, where their price is in the range of about 17 to $29 \mathrm{EUR} / \mathrm{m}^{2}$, e.g., Malé Chyndice, Lúčnica nad Žitavou, Vel'ká Dolina, Bádice, Paňa, Tajná, Vel'ký, and Malý Cetín. Several studies have assessed land-use change in cities and suburban areas in selected European countries, e.g., in 26 European countries, including Slovakia [81]; a total of 9 cities within Slovakia, the Czech Republic, and Germany [24]; in 5 countries of Central and Eastern Europe, including Slovakia [82]; in 283 European regions of 27 European countries within Eastern European region, including Slovakia [44]. Data from the city of Nitra were also used in the evaluation of all these studies. The results of these studies say that except for Slovakia, in all Eastern European countries that recently joined the European Union, the trend of the rate of urban growth has accelerated since 2000 [81]. Suburban areas of Poland, Hungary, and Slovakia present a contrast as these areas increased in density during the 1990s. There were many cities in the Czech Republic and Slovakia with declining densities during the 1990s. In the time period of 2000-2006, settlements in the countryside of all the countries in the study, apart from Slovakia, had decreasing density (Germany, Czech Republic, Hungary, Poland) [82]. Similarly, the results [24] point to an increase in built-up area at the expense of agricultural land, with the most significant increase in the municipalities around the city of Nitra.

Common features of suburbanization in municipalities in the Nitra district are similar to suburbanization processes in the example of Poland [83], which include the considerable distance from the city center, the dominance of the residential function and the singlefamily house, administrative autonomy, a considerable inflow of population from the nearby town, and good access to workplaces, especially in the city center. Suburbanization leads to increased commuting from the suburban zone to the city center [84]. Additionally, continuous high demand as a result of labor mobilization to nearby industrial zones and industrial parks within the district of Nitra should be mentioned as a sign.

Suburbanization, as a process of the gradual "spillover" of the city into the country, is one of the most important processes changing the current landscape [85], increasingly affecting the whole countryside; it is no longer restricted to the urban fringe zones [62]. Due to the expanding suburbanization processes into the country, conflicts may arise between the individual functions of the country with regard to the optimal performance of these functions [49]. A report published by the European Environment Agency [86] identifies suburbanization as a key process currently taking place in EU countries, with several negative impacts on the landscape, including a number of environmental problems. Local governments may also be caught in the crossfire of conflicting local interests, especially in those settlements where they undertake or support intense suburbanization [11]. The peri-urban landscape is a depository of quality, unrecognized in terms of aesthetics and perception, and it becomes a place where we can design public spaces to identify growing conditions and ecosystem services for the communities [87]. Municipalities should regulate new developments or the arrival of new inhabitants [15]. Compact development requires public guidance and rules that encourage geographic limits. Incentives for compact development, with appropriate transportation links and access to nature, should be combined with limitations on sprawl by withholding infrastructure investments and prohibiting environmentally damaging water supply and sewage disposal practices [88]. While rural areas are confronted with a number of problems, it is necessary to bear in mind that the countryside is the place where the relationships of the population and their decisions 
shape the appearance of the village and the surrounding countryside. At present, the countryside is considered an attractive place to live, and urban dwellers increasingly prefer it. An active community approach by individual municipalities can help the quality of life and earlier community development and is probably more effective [34]. Assessment of urbanization and suburbanization patterns and processes in the European Union is becoming increasingly urgent for the formulation of common territorial policies [44]. Longterm joint monitoring of land-use efficiency has proven to be an essential informative tool when designing policies capable of promoting truly sustainable uses of land [89]. Verification of these conclusions, using the results obtained by us, can be performed by further detailed research.

Author Contributions: Conceptualization and methodology-Z.P., R.M., G.B., and H.G.; data preparation-Z.P. and R.M.; data analysis-G.B. and H.G.; data curation-Z.P., R.M., G.B., and H.G.; writing-Z.P.; visualization-Z.P. and G.B., H.G.; supervision-Z.P. and H.G.; correspondence-Z.P. All authors have read and agreed to the published version of the manuscript.

Funding: This research was supported by project No. 052/2020/OPII/VA “Scientific support of climate change adaptation in agriculture and mitigation of soil degradation" (implemented within the ERDF, Operational Programme Integrated Infrastructure).

Institutional Review Board Statement: Not applicable.

Informed Consent Statement: Not applicable.

Data Availability Statement: Not applicable.

Conflicts of Interest: No potential conflict of interest was reported by the authors.

\section{References}

1. Matlovič, R. Teoreticko-metodologický rámec komplexnej geografickej interpretácie priestorovej štruktúry mesta. [Theoretical and methodological framework of a complex geographical interpretation of the spatial structure of the city]. Prešov: Prešovská univerzita. Folia Geogr. 2002, 6, 127-143. (In Slovak)

2. Lopez, R.A.; Adelaja, A.O.; Andrews, M.S. The Effects of Suburbanization on Agriculture. Am. J. Agric. Econ. 1988, 70, 346-358. [CrossRef]

3. Kruszyna, M.; Śleszyński, P.; Rychlewski, J. Dependencies between Demographic Urbanization and the Agglomeration Road Traffic Volumes: Evidence from Poland. Land 2021, 10, 47. [CrossRef]

4. Mantey, D.; Sudra, P. Types of suburbs in post-socialist Poland and their potential for creating public spaces. Cities 2019, 88, 209-221. [CrossRef]

5. Pobłocki, K. Suburbanization of the Self: Religious Revival and Socio-Spatial Fragmentation in Contemporary Poland. Int. J. Urban Reg. Res. 2021, 45, 39-60. [CrossRef]

6. Ot’ahel', J.; Solár, V.; Matlovič, R.; Krokusová, J.; Pazúrová, Z.; Ivanová, M. Prímestská krajina: Analýza premien vplyvom suburbanizačných procesov v zázemí Prešova. [Suburban landscape: Analysis of changes due to suburbanization processes in the background of Prešov]. Geogr. Časopis/Geogr. J. 2020, 72, 131-155. (In Slovak) [CrossRef]

7. Bajmócy, P. Suburbanization in Hungary-Expect the agglomeration of Budapest. In Falvaktól a Kibertérig; Kovács, C., Ed.; SZTE Gazdaság-és Társadalomföldrajz Tanszék: Szeged, Hungary, 2007; pp. 139-149.

8. Kok, H.; Kovács, Z. The process of suburbanization in the agglomeration of Budapest. Neth. J. Hous. Built Environ. 1999, 14, 119-141. [CrossRef]

9. Szmytkie, R. The impact of residential suburbanization on changes in the morphology of villages in the suburban area of Wrocław, Poland. Environ. Socio-Econ. Stud. 2020, 8, 24-43. [CrossRef]

10. Stanilov, K.; Hirt, S. Sprawling Sofia Postsocialist Suburban Growth in the Bulgarian Capital. In Confronting Suburbanization: Urban Decentralization in Postsocialist Central and Eastern Europe; Stanilov, K., Sýkora, L., Eds.; John Wiley \& Sons, Inc.: Hoboken, NJ, USA, 2014; Chapter 6; pp. 163-191. [CrossRef]

11. Timár, J.; Váradi, M.M. The uneven development of suburbanization during transition in Hungary. Eur. Urban Reg. Stud. 2001, 8, 349-360. [CrossRef]

12. Gnatiuk, O. Demographic dimension of suburbanization in Ukraine in the light of urban development theories. AUC Geogr. 2017, 52, 151-163. [CrossRef]

13. Biolek, J.; Andráško, I.; Malý, J.; Zrůstová, P. Interrelated aspects of residential suburbanization and collective quality of life: A case study in Czech suburbs. Acta Geogr. Slov. 2017, 57, 65-75. [CrossRef]

14. Repaská, G.; Vilinová, K.; Šolcová, L. Trends in development of residential areas in suburban zone of the city of Nitra (Slovakia). Eur. Countrys. 2017, 2, 287-301. [CrossRef] 
15. Hlaváček, P.; Kopáček, M.; Horáčková, L. Impact of Suburbanisation on Sustainable Development of Settlements in Suburban Spaces: Smart and New Solutions. Sustainability 2019, 11, 7182. [CrossRef]

16. Richardson, H.W.; Bae, C.H.C. (Eds.) Urban Sprawl in Western Europe and the United States, 1st ed.; Routledge: London, UK, 2004; 344p. [CrossRef]

17. Wnęk, A.; Kudas, D.; Stych, P. National Level Land-Use Changes in Functional Urban Areas in Poland, Slovakia, and Czechia. Land 2021, 10, 39. [CrossRef]

18. Repaská, G. Rezidenčná Suburbanizácia Miest Nitrianskeho Samosprávneho Kraja (Empirický Príklad Mesta Nitra) [Residential Suburbanization of the Cities of the Nitra Self-Governing Region (Empirical Example of the City of Nitra)]; Univerzita Konštantína Filozofa $\mathrm{v}$ Nitre, Fakulta Prírodných Vied: Nitra, Slovakia, 2012; 127p. (In Slovak)

19. Gajdoš, P.; Moravanská, K. Suburbanizácia a jej Podoby na Slovensku. [Suburbanization and its Forms in Slovakia]; VEDAVydavatel'stvo SAV: Bratislava, Slovakia, 2011; 205p. (In Slovak)

20. Šveda, M.; Križan, F. Prejavy komerčnej suburbanizácie vo vybraných odvetviach hospodárstva v zázemí Bratislavy [The manifestation of commercial suburbanization in the selected sectors of economy in the hinterland of Bratislava]. Ekon. Časopis 2012, 60, 460-481. (In Slovak)

21. Székely, V. Urban-rural relations as a source of transfer of knowledge: Some examples from rural surrounding of Bratislava. Rural Areas Dev. 2013, 10, 59-79. [CrossRef]

22. Dická, J. Suburbanizácia mesta Košice a jeho zázemia [Suburbanization of Košice and its surrounding]. Geogr. Rev. 2006, 2, 295-309. (In Slovak)

23. Matlovič, R.; Sedláková, A. The impact of suburbanisation in the hinterland of Prešov (Slovakia). Morav. Geogr. Rep. 2007, 15, 22-31.

24. Izakovičová, Z.; Mederly, P.; Petrovič, F. Long-Term Land Use Changes Driven by Urbanisation and Their Environmental Effects (Example of Trnava City, Slovakia). Sustainability 2017, 9, 1553. [CrossRef]

25. Hardi, T.; Repaská, G.; Veselovský, J.; Vilinová, K. Environmental Consequences of the Urban Sprawl in the Suburban Zone of Nitra. An Analysis Based on Landcover Data. Geogr. Pannonica 2020, 24, 205-220. [CrossRef]

26. Székely, V. The Pauperisation and Suburbanisation of the Countryside: Two Aspects of Spatially Differentiated Post-communist Development in Slovakia. In Three Decades of Transformation in the East-Central European Countryside; Bański, J., Ed.; Springer: Cham, Switzerland, 2019; pp. 263-284. [CrossRef]

27. Slaev, A.D.; Nedović-Budić, Z.; Krunić, N.; Petrić, J.; Daskalova, D. Suburbanization and sprawl in post-socialist Belgrade and Sofia. Eur. Plan. Stud. 2018, 26, 1389-1412. [CrossRef]

28. Gałka, J.; Warych-Juras, A. Suburbanization and migration in Polish metropolitan areas during political transition. Acta Geogr. Slov. 2018, 58, 63-72. [CrossRef]

29. Dumitrache, L.; Zamfir, D.; Nae, M.; Simion, G.; Stoica, I.V. The Urban Nexus: Contradictions and Dilemmas of (Post)Communist (Sub)Urbanization in Romania. Hum. Geogr. J. Stud. Res. Hum. Geogr. 2016, 10, 39-58. [CrossRef]

30. Sýkora, L.; Ouředníček, M. Sprawling post-communist metropolis: Commercial and residential suburbanization in Prague and Brno, the Czech Republic. In Employment Deconcentration in European Metropolitan Areas; Razin, E., Ed.; Springer: Berlin/Heidelberg, Germany, 2007; Volume 91, pp. 209-233.

31. Kladivo, P.; Roubínek, P.; Opravil, Z.; Nesvadbová, M. Suburbanization and local governance-Positive and negative forms: Olomouc case study. In Bulletin of Geography. Socio-Economic Series; Szymańska, D., Rogatka, K., Eds.; Nicolaus Copernicus University: Toruń, Poland, 2015; Volume 27, pp. 95-107.

32. Kubeš, J.; Nováček, A. Suburbs around the Czech provincial city of České Budějovice-Territorial arrangement and problems. Hung. Geogr. Bull. 2019, 68, 65-78. [CrossRef]

33. Kuta, D.; Teichmann, M.; Hurdalkova, L. Process of suburbanization in polycentric agglomerations. Int. Multidiscip. Sci. GeoConf. SGEM Sofia 2019, 19, 1027-1033. [CrossRef]

34. Stonawská, K.; Vaishar, A. Differentiation and typology of Moravian countryside. Eur. Countrys. 2018, 10, 127-140. [CrossRef]

35. Vaishar, A.; Št'astná, M.; Zapletalová, J.; Nováková, E. Is the European countryside depopulating? Case study Moravia. J. Rural Stud. 2020, 80, 567-577. [CrossRef]

36. Timár, J. The main features of suburbanization in the Great Hungarian Plain. Landsc. Urban Plan. 1992, 22, 177-187. [CrossRef]

37. Bajmócy, P.; Balizs, D. Rajka-Rapid changes of social, architectural and ethnic character of a cross-border suburban village of Bratislava in Hungary. In Mental Mapping. The Science of Orientation; New Approaches to Location-Spatial Patterns of the Global Economy Conference; Schenk Verlag: Passau, Germany, 2020; pp. 49-70. [CrossRef]

38. Rieniets, T. Shrinking Cities: Causes and Effects of Urban Population Losses in the Twentieth Century. Nat. Cult. 2009, 4, 231-254. [CrossRef]

39. Slaev, A.D.; Nikiforov, I. Factors of Urban Sprawl in Bulgaria. SPATIUM 2013, 29, 22-29. [CrossRef]

40. Bertaud, A. The spatial structures of central and eastern European cities. In The Urban Mosaic of Post-Socialist Europe: Space, Institutions and Policy; Tsenkova, S., Nedović-Budić, Z., Eds.; Springer: Berlin/Heidelberg, Germany, 2006; pp. 91-110.

41. Hung, T.; Yasuoka, Y. Remote sensing and GIS to study the sub-urbanization dynamics: A case study in northern Bangkok, Thailand. In The Chao Phraya Delta: Historical Development, Dynamics and Challenges of Thailand's Rice Bowl, Proceedings of the International Conference, Bangkok, Thailand, 12-15 December 2000; Kasetsart University: Bangkok, Thailand, 2000; pp. 111-123. 
42. Matsushitaa, B.; Xu, M.; Fukushima, T. Characterizing the changes in landscape structure in the Lake Kasumigaura Basin, Japan using a high-quality GIS dataset. Landsc. Urban Plan. 2006, 78, 241-250. [CrossRef]

43. Šveda, M. Suburbanizácia v zázemí Bratislavy z hl’adiska analýzy zmien krajinnej pokrývky. Geogr. Časopis/Geogr. J. 2011, 63, 155-173. (In Slovak)

44. Salvati, L.; Carlucci, M. Land-use structure, urban growth, and periurban landscape: A multivariate classification of the European cities. Environ. Plan. B Plan. Des. 2015, 42, 801-829. [CrossRef]

45. Krajewski, P. Landscape changes in selected suburban area of Bratislava (Slovakia). In 2016: Landscape and Landscape Ecology. Proceedings of the 17th International Symposium on Landscape Ecology, Nitra, Slovakia, 27-29 May 2015; Halada, L'., Bača, A., Boltižiar, M., Eds.; Institute of Landscape Ecology, Slovak Academy of Sciences, Branch Nitra: Bratislava, Slovakia, 2016 ; pp. 110-117.

46. Stręk, Ż.; Postek, P.; Sobczak, A.; Rybaczek, P. Suburbanization as a problem of rural development. E3S Web Conf. 2020, 171, 02013. [CrossRef]

47. Cieślak, I.; Biłozor, A.; Szuniewicz, K. The Use of the CORINE Land Cover (CLC) Database for Analyzing Urban Sprawl. Remote Sens. 2020, 12, 282. [CrossRef]

48. Cegielska, K.; Noszczyk, T.; Kukulska, A.; Szylar, M.; Józef Hernik, J.; Dixon-Gough, R.; Jombach, S.; Valánszki, I.; Filepné Kovács, $\mathrm{K}$. Land use and land cover changes in post-socialist countries: Some observations from Hungary and Poland. Land Use Policy 2018, 78, 1-18. [CrossRef]

49. Haase, D.; Walz, U.; Neubert, M.; Rosenberg, M. Changes to Central European landscapes-Analysing historical maps to approach current environmental issues, examples from Saxony, Central Germany. Land Use Policy 2007, 24, 248-263. [CrossRef]

50. Busko, M.; Szafranska, B. Analysis of Changes in Land Use Patterns Pursuant to the Conversion of Agricultural Land to Non-Agricultural Use in the Context of the Sustainable Development of the Malopolska Region. Sustainability 2017, 10, 136. [CrossRef]

51. Triantakonstantis, D.; Stathakis, D. Examining urban sprawl in Europe using spatial metrics. Geocarto Int. 2015, 30, 1092-1112. [CrossRef]

52. Kanianska, R.; Kizeková, M.; Nováček, J.; Zeman, M. Land-use and land-cover changes in rural areas during different political systems: A case study of Slovakia from 1782 to 2006. Land Use Policy 2014, 36, 554-566. [CrossRef]

53. Pazúr, R.; Bolliger, J. Land Changes in Slovakia: Past Processes and Future Directions. Appl. Geogr. 2017, 85, 163-175. [CrossRef]

54. Nagyváradi, L.; Szebényi, A.; Rábay, A. Modeling the suburbanization of the Budapest agglomeration (Hungary) with GIS methods the aspect of the sustainable development. In Proceedings of the 2011 International Conference on Asia Agriculture and Animal IPCBEE, Hong Kong, China, 2-3 July 2011; Volume 13, 6p.

55. Kočický, D.; Špilárová, I.; Rákayová, R.; Zvara, I.; Pauk, J.; Maretta, M.; Ivanič, B.; Pondelik, R.; Chovan, J.; Paczelt, F.; et al. Regionálny Územný Systém Ekologickej Stability Okresu Nitra. [Regional Territorial System of Ecological Stability of the Nitra District]; Banská Štiavnica: Esprit: Nitra, Slovakia, 2019; 339p, Available online: http:/ / download.sazp.sk/RUSES_II/ (accessed on 26 November 2020). (In Slovak)

56. Cadastral Portal. Cadastral Portal Office of Geodesy, Cartography and Cadastre of the Slovak Republic. Available online: https: / / www.katasterportal.sk/ kapor/ (accessed on 26 November 2020).

57. DATAcube. Demography and Housing in the Slovak Republic. Available online: http:/ / datacube.statistics.sk/ (accessed on 26 November 2020).

58. Horecký, M. Historický Lexikón obcí Slovenskej Republiky 1970-2001. [Historical Lexicon of Municipalities of the Slovak Republic 1970-2001]; Štatistický úrad SR: Bratislava, Slovakia, 2003; 508p. (In Slovak)

59. Podmanická, Z.; Škápik, P.; Krčméryová, E.; Juhaščíková, I.; Štukovská, Z.; Radová, V.; Kotlár, J.; Smutná, K. Štatistický Lexikón obcí Slovenskej Republiky 2011. [Statistical Lexicon of Municipalities of the Slovak Republic 2011]; Štatistický úrad SR: Bratislava, Slovakia, 2014; 336p. (In Slovak)

60. Borana, S.L.; Yadav, S.K. Urban Growth Analysis Using Shannon's Entropy: A Case Study of Jodhpur City. Int. J. Adv. Res. Comput. Sci. Manag. Stud. 2017, 5, 50-57.

61. Hasse, J.E.; Lathrop, R.G. Land resource impact indicators of urban sprawl. Appl. Geogr. 2003, 23, 159-175. [CrossRef]

62. Antrop, M. Landscape change and the urbanization process in Europe. Landsc. Urban Plan. 2004, 67, 9-26. [CrossRef]

63. Łupiński, W. Suburbanisation in Poland. Geogr. Inf. 2014, 18, 104-113. [CrossRef]

64. Dyszy, M. Changes in land usage of rural areas in suburban area of Katowice conurbation. Int. Sci. Conf. Geobalc. 2018, 251-260. [CrossRef]

65. European Environment Agency. Land Accounts for Europe 1990-2000. 2006. 112p. Available online: https://www.eea.europa. eu/publications/eea_report_2006_11 (accessed on 4 January 2021).

66. Lucy, W.H.; Phillips, D.L. The post-suburban era comes to Richmond: City decline, suburban transition, and exurban growth Landsc. Urban Plan. 1997, 36, 259-275. [CrossRef]

67. Amato, F.; Maimone, B.A.; Martellozzo, F.; Nolè, G.; Murgante, B. The Effects of Urban Policies on the Development of Urban Areas. Sustainability 2016, 8, 297. [CrossRef]

68. Commission of the European Communities. Thematic Strategy for Soil Protection. 2006. 12p. Available online: https://eur-lex. europa.eu/legal-content/EN/TXT/?uri=CELEX\%3A52006DC0231 (accessed on 4 January 2021). 
69. Commission Staff Working Document. Guidelines on Best Practice to Limit, Mitigate or Compensate Soil Sealing. 2012. 61p. Available online: https://ec.europa.eu/environment/soil/pdf/guidelines/EN\%20-\%20Sealing\%20Guidelines.pdf (accessed on 4 January 2021).

70. Xu, Y.; Zhang, X. The residential resettlement in suburbs of Chinese cities: A case study of Changsha. Cities 2017, 69, 46-55. [CrossRef]

71. Kostelecký, T.; Čermák, D. Metropolitan Areas in the Czech Republic-Definitions, Basic Characteristics, Patterns of Suburbanisation and Their Impact on Political Behaviour. In Sociologické Studie/Sociological Studies, 04/03; Institute of Sociology of the Academy of Sciences of the Czech Republic: Prague, Czech Republic, 2004; 63p.

72. Preweda, E.; Jasińska, E. Organization of the Building Space of Developments and Its Impact on Residential Housing Prices. Sustainability 2020, 12, 7622. [CrossRef]

73. Sopirová, A. Rezidenčná Suburbanizácia a jej Odraz vo Vidieckych Sídlach Ležiacich v Zázemí Mesta Bratislavy. [Residential Suburbanization and Its Reflection in Rural Settlements at Bratislava Surroundings]; Člověk, stavba a územní plánování V. Fakulta stavební ČVUT v PrazeCzech Technical University in Prague: Prague, Czech Republic, 2011; pp. 57-65. (In Slovak)

74. Basic Environmental Information on Slovak Settlements. Available online: http://www.beiss.sk/ (accessed on 17 January 2021).

75. Information about Municipalities and Cities in Slovakia. E-OBCE.sk. Available online: https://www.e-obce.sk/okres/nitra.html (accessed on 17 January 2021).

76. Korec, P.; Popjaková, D. Priemysel v Nitre: Globálny, Národný a Regionálny Kontext. [Industry in Nitra: Global, National and Regional Context]; Prírodovedecká Fakulta Univerzity Komenského v Bratislave: Bratislava, Slovakia, 2019; 210p. (In Slovak)

77. Pret'o, A. Analýza Priemyselných Parkov v Slovenskej Republike. [Analysis of Industrial Parks in the Slovak Republic]; Ministerstvo hospodárstva SR: Bratislava, Slovakia, 2018; 90p.

78. Ministry of Economy of the Slovak Republic. Industrial Zones of Slovakia. MH Invest. Available online: https://www. priemyselneparkyslovenska.sk/ (accessed on 26 November 2020).

79. Portal Engineering. Available online: https:/ / www.engineering.sk/ (accessed on 26 November 2020).

80. Palicki, S.; Rącka, I. Influence of Urban Renewal on the Assessment of Housing Market in the Context of Sustainable Socioeconomic City Development. Lect. Notes Inst. Comput. Sci. Soc. Inform. Telecommun. Eng. 2016, 166, 851-860. [CrossRef]

81. Siedentop, S.; Fina, S. Who sprawls most? Exploring the patterns of urban growth across 26 European countries. Environ. Plan. A 2012, 44, 2765-2784. [CrossRef]

82. Schmidt, S.; Fina, S.; Siedentop, S. Post-socialist Sprawl: A Cross-Country Comparison. Eur. Plan. Stud. 2015, 23, 1357-1380. [CrossRef]

83. Więcław-Michniewska, J. The Suburbanization Process in Poland and New Spatial Form. In International Conference Textbook "Studying, Modeling and Sense Making of Planet Earth"; Department of Geography of the University of the Aegean in Lesvos: Lesvos, Greece, 2008; pp. 58-66.

84. Tammaru, T. Suburban Growth and Suburbanisation under Central Planning: The Case of Soviet Estonia. Urban Stud. 2001, 38, 1341-1357. [CrossRef]

85. Chuman, T.; Romportl, D. Spatial pattern of suburbanization in the Czech Republic. Venk. Kraj. 2008, 35-39. Available online: http:/ / www.suburbanizace.cz/dokumenty/VK_08_TCH_DR_en.pdf (accessed on 20 January 2021).

86. European Environment Agency. Urban Sprawl in Europe. The Ignored Challenge; EEA: Copenhagen, Denmark, 2006; 57p.

87. Martinelli, N.; D'Onghia, V. The dichotomy between city and countryside in the Italian experience of regional landscape planning. Upl. J. Urban Plan. Landsc. Environ. Des. 2020, 5, 141-160. [CrossRef]

88. Lucy, W.H.; Phillips, D.L. Suburban decline: The next urban crisis. Issues Sci. Technol. 2000, 17, 55-62.

89. Zitti, M.; Ferrara, C.; Perini, L.; Carlucci, M.; Salvati, L. Long-Term Urban Growth and Land Use Efficiency in Southern Europe: Implications for Sustainable Land Management. Sustainability 2015, 7, 3359-3385. [CrossRef] 